\title{
Mercury Export From Freshwater to Estuary: Carbocentric Science Elucidates the Fate of a Toxic Compound in Aquatic Boreal Environments
}

\author{
Maud Demarty ${ }^{1 *}$, François Bilodeau ${ }^{2 \dagger}$ and Alain Tremblay ${ }^{2 \dagger}$ \\ ${ }^{1}$ Aqua-Consult, Montréal, QC, Canada, ${ }^{2}$ Direction Environnement, Hydro-Québec, Montréal, QC, Canada
}

\section{OPEN ACCESS}

Edited by:

Vinicius Fortes Farjalla,

Federal University of Rio de Janeiro,

Brazil

Reviewed by:

Daniele Kasper,

Federal University of Rio de Janeiro,

Brazil

Jean Remy Davee Guimaraes, Federal University of Rio de Janeiro,

Brazil

Heng Yao,

Institute of Geochemistry (CAS), China

*Correspondence:

Maud Demarty

maud.demarty@aquaconsult.ca

tThese authors have contributed equally to this work and share last authorship

Specialty section: This article was submitted to

Freshwater Science,

a section of the journal

Frontiers in Environmental Science

Received: 19 April 2021 Accepted: 03 June 2021

Published: 23 June 2021

Citation:

Demarty M, Bilodeau Fand Tremblay A

(2021) Mercury Export From

Freshwater to Estuary: Carbocentric

Science Elucidates the Fate of a Toxic

Compound in Aquatic

Boreal Environments.

Front. Environ. Sci. 9:697563.

doi: 10.3389/fenvs.2021.697563
The chemistry of mercury in freshwater systems, particularly man-made reservoirs, has received a great deal of attention owing to the high toxicity of the most common organic form, methylmercury. Although methylmercury bioaccumulation in reservoirs and natural lakes has been extensively studied at all latitudes, the fate of the different forms of mercury (total vs. dissolved; organic vs. inorganic) along the entire river-estuary continuum is less well documented. In fact, the difficulty of integrating the numerous parameters involved in mercury speciation in such large study areas, combined with the technical difficulties in sampling and analyzing mercury, have undoubtedly hindered advances in the field. At the same time, carbocentric science has grown exponentially in the last 25 years, and the common fate of carbon and mercury in freshwater has become increasingly clear with time. This literature review, by presenting the knowledge acquired in these two fields, aims to better understand the extent of mercury export from boreal inland waters to estuaries and to investigate the possible downstream ecotoxicological impact of reservoir creation on mercury bioavailability to estuarine food webs and local communities.

Keywords: mercury, organic matter, DOC, river continuum, reservoir, estuary

\section{INTRODUCTION}

Concentrations of mercury in ambient air and water are extremely low and so do not constitute a significant source of human exposure to mercury (Clarkson 2002; Goyer and Clarkson, 2001). Rather, humans are generally exposed to mercury $(\mathrm{Hg})$ through diet, and fish consumption is the main source of this exposure (Clarkson 2002; Health Canada, 2007; Ferreira-Rodriguez et al., 2021), with a growing concern regarding rice consumption in Asia (Kwon et al., 2018). The flooding of soil when hydroelectric reservoirs are impounded promotes the release of nutrients and increases bacterial activity and methylmercury bioavailability at the base of the food chain. The mercury is then transferred from lower to higher trophic levels, from plankton to fish. This temporary phenomenon has been studied extensively in various regions of the world (Verta et al., 1986; Verdon et al., 1991; Porvari, 1995; Rudd, 1995; Porvari, 1998; Ikingura and Akagi, 2003; Bodaly et al., 2007; Teisserenc et al., 2014). The health risks associated with increased Hg levels in reservoir fish, which impact sport fishers and communities that rely on fish as a traditional food (Moriarity et al., 2020a), have raised concerns about the environmental footprint of hydropower. Concerns have also been raised about 
the transport of $\mathrm{Hg}$ downstream to estuaries, which could potentially increase $\mathrm{Hg}$ bioavailability (Calder et al., 2016).

In the meantime, the worldwide increase in energy demand coupled with concerns about greenhouse gas emissions have put hydroelectricity in the forefront of green energies. The projected impacts of climate change on water resources and on floods and droughts are uncertain, and structural or functional adaptation measures will be needed to provide the required flexibility in hydropower management (ICOLD, 2016). Under these conditions, hydropower remains a key component in any renewable energy portfolio, as it is the only non-intermittent renewable that can meet both baseload and peak energy demands (Bates et al., 2008). Canada, Russia and Norway are among the world's major hydropower producers (International Hydropower Association, IHA) and they all still have high potential for hydropower development (Hoes et al., 2017). The boreal forest is the dominant biome in these countries, covering 33,46, and $18 \%$ of the Canadian, Russian and Norwegian landscapes respectively (Kuusela, 1992), and boreal biomes contain the highest density of freshwater systems on earth, hosting about $28.4 \%$ of the global lake area (Downing et al., 2006; Bravo et al., 2017). Given these hydrologic characteristics, it is not surprising that major hydropower developments in these countries are on rivers originating in or flowing through the boreal forest (ICOLD, 2021). Soils in the boreal forest are typically podzols, that is, gray soils that are thin, acidic and poor in nutrients, with limited soil microorganism activity due to the cold climate. Extensive networks of wetlands are also characteristic of the boreal forest and play an important role in water filtration, flood and drought control, and carbon storage (RAMP, 2021). Another key parameter in the boreal biome is seasonality, which drives metabolic processes and the carbon cycle across the entire aquatic web (Huttunen et al., 2004; Mattson et al., 2005; Agren et al., 2007; Kortelainen et al., 2013). Since the boreal biome is likely to be further exploited in the future to meet the increasing energy demand, the impact of reservoir creation must be studied with the new perspectives recent science provides.

Although numerous studies deal with $\mathrm{Hg}$ accumulation in freshwater food webs, only a few focus on $\mathrm{Hg}$ export downstream of reservoirs to estuaries (Taylor et al., 2019). Some studies address the impact of reservoir impoundment in situ as well as on downstream ecosystems in Canada (Schetagne et al., 2000; Anderson, 2011), including some critical voices (Calder et al., 2016). The complexity of $\mathrm{Hg}$ speciation has been addressed in many publications, with studies examining its different aspects (see Lucotte et al., 2016, for a review of factors studied). However, our understanding of this phenomenon along the aquatic continuum from source to estuary is still in its infancy (Morel et al., 1998; Schartup et al., 2016; Skrobonja, 2019).

Concomitantly, research in carbon science and accompanying data collection efforts have increased exponentially since the early 2000s, leading to a better understanding of inputs from inland waters to the global carbon budget (Cole et al., 2007; LaBrie et al., 2020). More refined chemical analysis methods have improved our understanding of the relationship between the nature of organic matter (OM; particulate, colloid, dissolved) (Massicote et al., 2017) and both trace metal processing (Jokinen et al., 2020) and $\mathrm{Hg}$ bioavailability in freshwater and estuarine systems (Quémerais et al., 1998; Soerensen et al., 2017; Lavoie et al., 2019). Step by step, the strong link between $\mathrm{Hg}$ in water and the carbon cycle in aquatic systems has been clarified in the last 20 years. Because studies of carbon speciation along the river continuum are more common than those of mercury speciation, and because mercury measurement methods are more complicated and expensive than methods for measuring carbon, studies on the fate of mercury in aquatic environments would benefit from quantitative determination of the relationship between $\mathrm{OM}$ and $\mathrm{Hg}$. To do this, we need to determine the gaps in our knowledge, whether they be in understanding the chemical or biological processes involved in $\mathrm{Hg}$ and carbon cycles or in our knowledge of the ecosystem characteristics related to these processes.

This article thus aims to provide an overview of studies of the transport and fate of mercury along the river continuum and in estuaries, focusing on how this affects potential mercury transfer to organisms. The objective is to demonstrate the fundamental link between mercury and carbon cycles and the need to systematically integrate this perspective in future studies on the fate of mercury in aquatic systems. The focus is neither on reservoir science nor on specific values but rather on the processes occurring from source (reservoir or natural lake) to downstream estuary. In terms of boreal systems in Québec, Canada, the question is whether existing studies can be used by scientists and managers to assess the impacts of $\mathrm{Hg}$ transport from reservoir to estuary and whether these impacts are limited and cease where the influence of freshwater is no longer detected.

\section{MeHg AND ORGANIC MATTER, A PARALLEL FATE IN LAKES AND RESERVOIRS}

The data found in the literature on mercury concentrations in natural waterbodies are wide-ranging and difficult to compare, not only because of natural variations in the concentrations and species of this metal in water but also due to analytical difficulties and differences (Boszke et al., 2002). Owing to the temporal and spatial scales involved, there is a paucity of studies comparing natural and anthropogenic systems, especially those that target the entire aquatic continuum from lake or reservoir to estuary. Therefore, the knowledge on biological and chemical processes in natural systems is often generalized, modelled (Zhu et al., 2018) and tentatively applied to reservoirs, as a first step to new studies. In this section, the extent to which processes involving $\mathrm{OM}$ in lakes and in reservoirs can elucidate those involving mercury compounds will be explored. The carbon cycle has been in the spotlight for the past 10 years and the tremendous advances made in determining $\mathrm{OM}$ composition have improved our understanding of the strong links between OM and mercury compounds. This review thus attempts to combine carbocentric limnology (Prairie, 2008) and "mercury-centric" knowledge on reservoirs and lakes as a first step in understanding the downstream fate of these molecules in rivers and estuaries. 


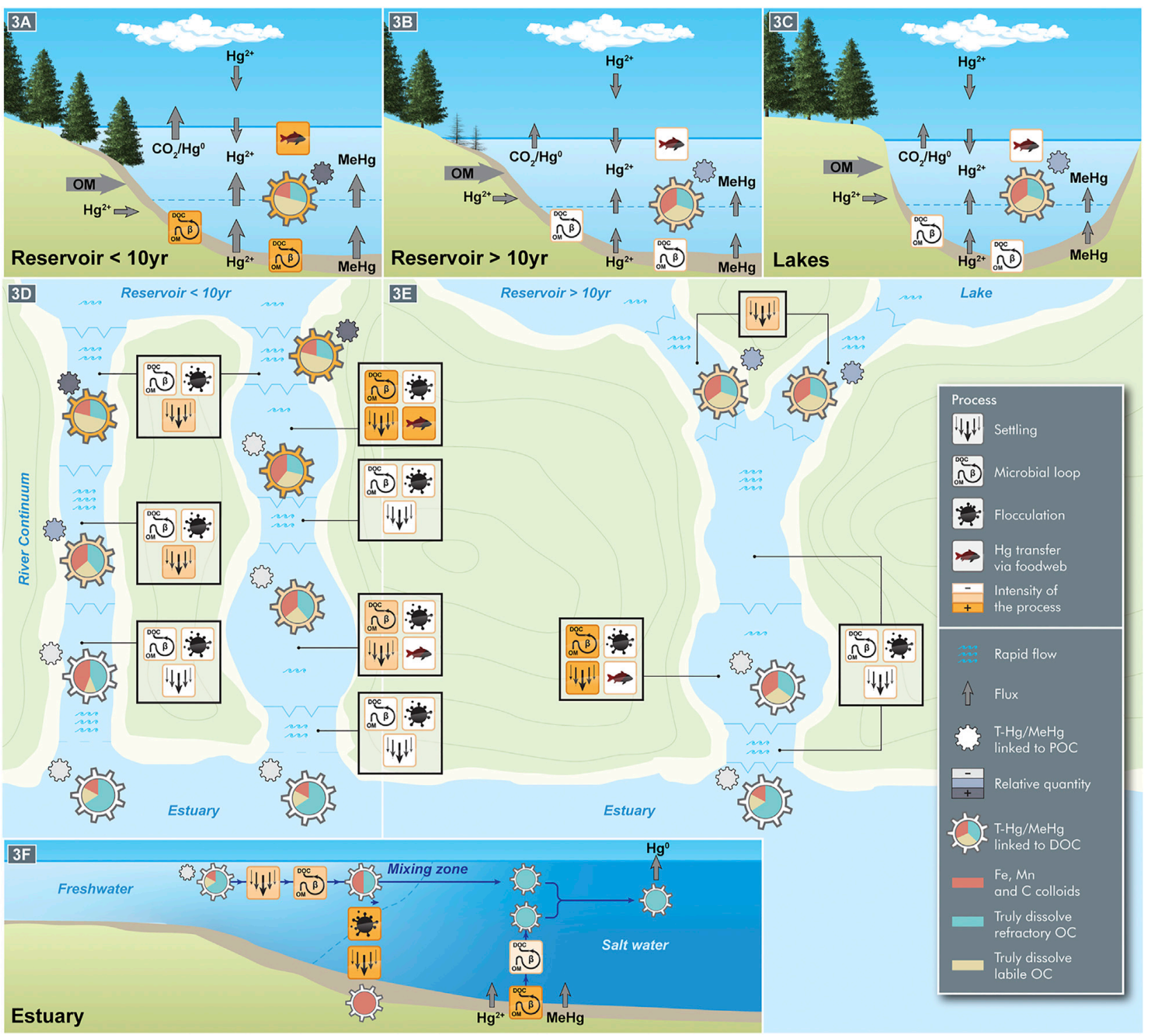

FIGURE 1 | Conceptual summary of the fate of carbon and mercury compounds in their transport from reservoirs and lakes to estuaries through different river continuums. The magnitude of the physical, chemical and biological processes and fluxes depends on ecosystem type: young reservoir (A), old reservoir (B), lake (C), river with or without riverine lakes (D,E), and estuary (F). Young reservoirs ( $<10$ years) present higher bacterial activity, which leads to higher concentrations of the studied components, namely total mercury and methylmercury (T-Hg/MeHg) linked to particulate organic carbon (POC) or to dissolved organic carbon (DOC). The dissolved fraction is detailed according to its speciation, i.e., molecular size and lability: colloids (size fraction between a few nanometers and 0.45 um); truly dissolved (size fraction $<0.45 \mu \mathrm{m}$ ) but refractory $\mathrm{OC}$; and truly dissolved (size fraction $<0.45 \mu \mathrm{m}$ ) labile $\mathrm{OC}$, this latter being rapidly consumed by heterotrophs. As indicated in the Conclusion herein, $\mathrm{T}-\mathrm{Hg} / \mathrm{MeHg}$ linked to POC rapidly decreases along the aquatic continuum owing to settling and flocculation. As for T-Hg/MeHg linked to DOC, the concentration decrease along the aquatic continuum is intimately related to DOC speciation: colloids tend to flocculate; labile DOC enters the bacterial loop and food chain; and the truly dissolved refractory fraction dominates at the river mouth. In the estuary, the changes in ionic strength promote flocculation and the scavenging effect, which immobilize $\mathrm{Hg}$ in the sediment and reduce its bioavailability to the entire food web.

Although boreal lakes and reservoirs differ in many respects, including age, residence time, mean water temperature, and the origin and quality of the OM available (Kalff, 2002; Tadonléké et al., 2012), carbocentric science teaches us that planktonic food webs in northern temperate and boreal lakes as well as in reservoirs are subsidized by allochthonous OM in a large proportion (Del Giorgio et al., 1999; Cole et al., 2002; Cole et al., 2006; Tadonléké et al., 2012; Emery et al., 2015;
Grosbois et al., 2020). In fact, terrestrial soils typically provide very active loci for the decomposition of $\mathrm{OM}$, which is exported to and through aquatic systems (Cole et al., 2007). Allochthonous $\mathrm{OM}$ is more recalcitrant to biodegradation and more susceptible to photochemical mineralization, but this last process is limited by the high proportion of humic acids (vs. fulvic acids) that dominate in the $\mathrm{OM}$ of boreal lakes and reservoirs (Bastien, 2005). When terrestrial ecosystems are flooded for reservoir 
creation, allochthonous carbon and nutrients are rapidly released in the water column, enhancing bacterial productivity and stimulating overall biological production in the reservoir ecosystem ("trophic upsurge," Kalff, 2002; Figure 1A), including the plankton and fish communities (Marty and Planas, 2005; Planas et al., 2005; Tadonléké et al., 2005). However, because of the lower carbon stock compared to temperate and tropical areas, this trophic upsurge is limited in time and amplitude in the northeastern boreal region of Quebec, Canada (Blais et al., 2005). As a result, reservoirs remain oligotrophic even in the first few years after flooding, resembling natural lakes in the region in this respect (Schetagne, 1994; Bogard and Del Giorgio, 2016). Autochthonous labile (easily degradable) OM (phytoplanktonderived organic compounds), although present in smaller quantities, has been shown to enhance overall bacterial activity and thus promote the incorporation of flooded allochthonous OM, which is less labile, at the bacterial level (Guillemette et al., 2015) or at a higher level in the trophic chain. In fact, Grosbois et al. (2020) recently demonstrated that the efficiency of zooplankton in a boreal lake in transferring autochthonous and allochthonous carbon is equivalent, suggesting that the breakdown of terrestrial detritus and recalcitrant dissolved high-molecular-weight humic substances may be facilitated by co-metabolism using carbon of algal origin (labile autochthonous carbon). The Hg-centric science led to the same findings: the bioavailability of labile carbon in newly flooded areas or in productive lakes promotes bacterial activity (and, in some cases, in deep or warm temperate/tropical waters, anoxia), which, in turn, results in increased mercury methylation rates in the water column and in sediments, and an increase in its final byproduct, MeHg (Mailman et al., 2006; Bo et al., 2016; Bravo et al., 2017; Figures 1A-C). The biological processes and bacterial groups involved in mercury methylation in anoxic sediments or in the water column are similar in natural lakes (Morel et al., 1998), reservoirs (Hall et al., 2005) and interestingly also in coastal systems (Skrobonja, 2019). In fact, a variety of anaerobes (particularly iron and sulfate-reducing bacteria) share a common gene pair $(h g c \mathrm{AB})$ that encodes proteins essential for $\mathrm{Hg}$ methylation (Regnell and Watras, 2019; Xu et al., 2021). The diversity of the methanogenic bacterial community in streams is positively linked to water temperature (Nagler et al., 2020), which suggests a lower diversity in boreal lakes and reservoirs, but one that should be quite similar throughout the boreal ecozone. Although mercury bioaccumulation occurs in both reservoirs and natural boreal lakes under the influence of many biotic and abiotic factors (Depew et al., 2013), in reservoirs, this phenomenon is distinguished by a drastic increase in nutrients and in the $\mathrm{OM}$ pool available in the water column in, approximately, the first ten years (Lucotte et al., 1999; Schetagne and Verdon, 1999) after their creation due to flooding and erosion. This results in a trophic upsurge, an increase in OM degradation demonstrated by higher dissolved $\mathrm{CO}_{2}$ concentrations (Tremblay et al., 2005) and substantial MeHg production (Louchouarn et al., 1993; Mucci et al., 1994; Houel et al., 2006; Turgeon et al., 2016). Interestingly, in a recent major study of numerous natural and flooded systems

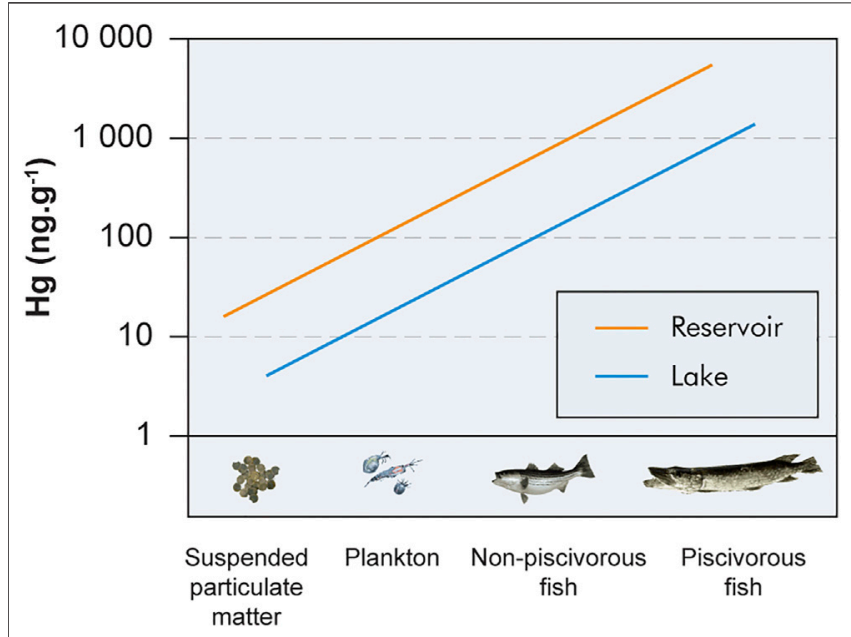

FIGURE 2 | Schematic representation of the transfer of mercury through the food chain in boreal lakes and young reservoirs ( $<10$ years; data adapted from Lucotte et al. (1999), Schetagne and Therrien (2013).

along the Romaine river in the boreal ecozone of Québec, Canada, De Bonville et al. (2020) found a strong correlation between two byproducts of $\mathrm{OM}$ degradation in aquatic systems: $\mathrm{MeHg}$ and $p \mathrm{CO}_{2}$ (Figures 1A-C). Photooxydation would only account for $6-28 \%$ of the OM degradation, while biological processes would dominate (Bastien, 2005). To our knowledge, no strong evidence has been discovered of an increase in methylation rates per unit of bacterial biomass during the trophic upsurge phase. Instead, an increase in bacterial biomass leading to higher $\mathrm{MeHg}$ production per unit of time has been found in reservoirs compared to natural systems. This is likely linked to the higher proportion of anoxic zones in reservoirs (deep parts of the highly dynamic main channel and shallower hypolimnia in the flooded bays) than in natural systems, which is conducive to the growth of the sulfatereducing bacterial community. In addition, the fact that $\mathrm{MeHg}$ production increases with a trophic upsurge implies that the sulfate-reducing bacterial community was present in soils before impoundment or that a transfer of the community from upstream non-flooded sites occurred and that, due to its functional and metabolic plasticity, this community rapidly responded to environmental changes (deeper waters, for example) to reach a metabolically stable state similar to that in natural lakes (Comte and Del Giorgio, 2011).

Therefore, since the pool and bioavailability of $\mathrm{MeHg}$ entering food webs through lower-trophic-level aquatic organisms (e.g., primary producers, zooplankton, insect larvae, and benthic organisms) is greater in reservoirs, $\mathrm{MeHg}$ concentrations measured in reservoir fish can reach maximum values of up to one order of magnitude greater than values recorded in natural lakes (Tremblay et al., 1996; Tremblay and Lucotte, 1997; Tremblay et al., 1998; St. Louis et al., 2004; Drott et al., 2008; Bilodeau et al., 2017). Data from several studies conducted in boreal lakes and reservoirs illustrate this difference in the initial pool of $\mathrm{MeHg}$ available (concentration) at the bottom of food webs (Figure 2). These data also show that, although different initial $\mathrm{MeHg}$ concentrations can be observed in food chains in 
natural and anthropogenic freshwater systems, similar slopes (i.e., biomagnification rates) are found, which supports equivalent levels of mercury transfer efficiency in both systems (Lucotte et al., 1999; Schetagne and Therrien, 2013).

Finally, wetlands, an important portion of the boreal landscape (e.g., 30\% in Ontario, Canada, McLaughlin, 2004; Gingras et al., 2016), represent a source of OM and $\mathrm{MeHg}$ for the catchments (St. Louis et al., 2004; Xu et al., 2021). Their hydrology and connectivity with the large watersheds typical of boreal biomes is not addressed here. It is assumed, however, that the lakes, reservoirs and rivers whose processes are described herein are the receptacles of net exports from these wetlands.

To summarize, the current knowledge tends to demonstrate that the chemical and biological pathways involved in the production of mercury compounds and the processing of $\mathrm{OM}$ are parallel and occur in a similar way in natural lakes and manmade reservoirs. Overall, in freshwater systems, the concentration of mercury compounds increases concomitantly with the increasing concentration of OM (Wetzel, 2001). Specifically, $\mathrm{MeHg}$ and/or total mercury (T-Hg) concentrations have been shown to be positively related to DOC (dissolved organic carbon), and more precisely to the concentration of aromatic molecules in the OM pool (Watras et al., 1998; Braaten et al., 2014; Lavoie et al., 2019; De Bonville et al., 2020), with the latter often considered to be of allochthonous origin (Lapierre and Del Giorgio, 2014). In fact, $\mathrm{Hg}$ has a high affinity for molecules containing reduced sulfur such as thiols, and the availability of these molecules in the system may control Hg-DOC associations and co-transport (Skyllberg et al., 2003; Ravichandran, 2004; French et al., 2014). This knowledge is crucial in understanding exportation processes downstream of lakes or reservoirs, as discussed in the following section.

\section{FROM RESERVOIRS OR LAKES TO ESTUARIES: EVIDENCE OF THE JOINT EXPORT OF CARBON AND MERCURY}

In the 1990s, our growing understanding of the chemical cycle and mercury bioaccumulation in several terrestrial and aquatic compartments of the biosphere led to questions about mercury transfer in lotic systems. Some of this research focused on the distance traveled by mercury compounds, while other substantial efforts targeted the chemical interactions between mercury compounds and organic/inorganic molecules or free ions. As for studies done on lakes and reservoirs, advances in knowledge in riverine systems underline the need to integrate the different approaches, in order to improve our understanding of the possible effects of anthropogenic disturbances on $\mathrm{Hg} / \mathrm{MeHg}$ availability in rivers.

\section{$\mathrm{T}-\mathrm{Hg}$ and $\mathrm{MeHg}$ Export Downstream of Reservoirs}

$\mathrm{MeHg}$ accumulation in fish downstream of boreal hydroelectric reservoirs has been measured in a few studies in the last 30 years, particularly in Canada. In 1994, in the Baie-James region, Brouard et al. reported the phenomenon in lake whitefish (Coregonus clupeaformis) $42 \mathrm{~km}$ downstream of La Grande 2 reservoir, in the La Grande River. The authors found that the feeding behavior of whitefish caught downstream of reservoirs switched from insectivory to piscivory. This kind of opportunistic behavior in whitefish was also suspected in a recent study by Moriarity et al. (2020b) in the Baie-James region. The finding of Brouard et al., led to a larger study investigating the export of mercury downstream in general, not only in the most common fish species in the region (longnose sucker, white sucker [Catostomus commersoni], lake whitefish, lake cisco [Coregonus artedii], northern pike, walleye and lake trout) but also in water quality throughout the entire La Grande complex (Schetagne and Verdon, 1999; Schetagne et al., 2000). These authors studied the impact of spills from Caniapiscau reservoir, 15 years after its creation, when dissolved $\mathrm{MeHg}$ concentrations had returned to values comparable to those in nearby natural lakes. The main result of this study was the demonstration of two conceptual axes of change for $\mathrm{MeHg}$ in freshwater systems according to residence time: 1) a vertical axis (bottom-up), with $\mathrm{MeHg}$ bioaccumulation in the trophic food webs of lentic systems, in which OM decomposition is promoted; and 2) a horizontal geographical axis, with $\mathrm{MeHg}$ transport from one lentic system to another through more dynamic lotic systems, in which $\mathrm{MeHg}$ speciation and linkage to the OM carrier may be modified by the chemical processes. In fact, the study results show greater $\mathrm{MeHg}$ accumulation in fish caught in riverine lakes downstream of the reservoir, up to $275 \mathrm{~km}$ away from the source, than in fish caught in a riverine station $355 \mathrm{~km}$ downstream of the reservoir. In this system, where total suspended solid (TSS) concentrations are very low (approx. 1 (NTU); Schetagne et al., 2006), MeHg was exported downstream of the reservoir mainly in the dissolved phase (64.3\%); suspended particulate matter (SPM) accounted for $33.2 \%$ of the $\mathrm{MeHg}$ exported, while zooplankton and phytoplankton represented only 1.54 and $0.85 \%$ of SPM respectively (dry weight; Schetagne et al., 2000). However, phytoplankton has been shown to represent more than $80 \%$ of drifting organisms by volume (Brouard et al., 1994). Schetagne et al. (2000) suggest that, in large riverine lakes, the increased residence time would allow the completion of the life cycle of the drifting zooplankton, and the filtration of the drifting SPM by local zooplankton, with both phenomena leading to $\mathrm{MeHg}$ accumulation in non-piscivorous and piscivorous fish. The authors also suggest that sedimentation of the heavier SPM would occur in the lentic areas and contribute to $\mathrm{MeHg}$ turnover (Figures 1D,E); this hypothesis is supported by Temnerud et al. (2007), who found that lakes can be loci of TOC-concentration decreases along the river continuum. However, these studies of the La Grande complex do not shed any light on the fate of the OM itself or on its role in promoting $\mathrm{MeHg}$ accumulation in riverine lakes. In fact, the spilling of a large amount of water, like that occurring during reservoir creation, would result in an increase in allochthonous OM in downstream riverine lakes, consisting of labile carbon from the large volume of algae exported. As discussed earlier, this input typically results in increased bacterial activity and a trophic 
upsurge in the receiving waterbody. Since $\mathrm{MeHg}$ was linked to the $\mathrm{OM}$, it would have prompted its bioaccumulation in the lakes food web. The fact that bioaccumulation was observed in two distant riverine lakes of the La Grande system provides evidence of the key role of the dissolved fraction in the fate of mercury downstream of the reservoir and lakes studied. It could be hypothesized that, in the system studied, $\mathrm{MeHg}$ was horizontally transferred through the river without a major change in speciation, and vertically accumulated by similar bacterial communities (see Introduction) dealing with similar $\mathrm{Hg}$ bioavailability. More recently, De Bonville et al. (2020) describe cumulative carbon processing in the Romaine complex, illustrated by an increase in dissolved $\mathrm{CO}_{2}$ concentrations along the cascade reservoirs, which would lead to environmental conditions more favorable to $\mathrm{Hg}$ methylation from the upstream to the downstream reservoirs. However, the average dissolved $\mathrm{MeHg}$ concentrations measured at stations in a $50 \mathrm{~km}$ stretch downstream of the last reservoir were significantly lower than in the four reservoirs further upstream. This suggests that export to the estuary was limited because the net $\mathrm{MeHg}$ production was negative in that downstream stretch of the river, with loss processes faster than accumulation (production) mechanisms.

However, this pattern seems to be specific to oligotrophic boreal systems. In fact, rivers cannot be considered to be passive pipes transporting OM and mercury (Cole et al., 2007). Dominique et al. (2007) showed that, in a river downstream of the productive tropical Petit-Saut reservoir (French Guyana), $\mathrm{MeHg}$ concentrations in biofilms and associated invertebrates and benthivorous fishes (Curimata cyprinoides) were much higher than in the reservoir itself. Similar observations were made downstream of the tropical Samuel and Balbina reservoirs (Kasper et al., 2012; Kasper et al., 2014); in these warm, productive rivers, higher cyanobacteria biovolumes induced higher $\mathrm{MeHg}$ production in periphyton (Lázaro et al., 2019). In these settings, the turbined water released downstream is extracted from the warm anoxic hypolimnion of the reservoir, where very favorable conditions for methylation are encountered, leading to dissolved $\mathrm{MeHg}$ concentrations of around $0.5 \mathrm{ng} / \mathrm{L}$ (Coquery et al., 2003; Kasper et al., 2014), i.e., ten times higher than what is observed in boreal systems (approx. $0.05 \mathrm{ng} / \mathrm{L}$; Schetagne et al., 2000). Since the range of $\mathrm{MeHg}$ concentrations and the limnological aspects are drastically different in equatorial and boreal ecozone, this review mainly focuses on the latter one.

\section{T-Hg and MeHg Links With Organic Matter in Rivers}

While the small number of available studies cited above undoubtedly support the fact that $\mathrm{MeHg}$ is exported from lakes and reservoirs toward estuaries, a larger number of studies have attempted to elucidate $\mathrm{MeHg}$ speciation and molecular linkage in rivers. Once again, advances in this area have been closely linked to our understanding of the carbon (and OM) cycle in freshwater. In the 1990s, a number of authors found that $\mathrm{MeHg}$ concentrations in rivers and streams were related to the color of the water, and thus potentially to OM (Lee and Iverfeld, 1991; Mierle and Ingram, 1991). The positive relationship between $\mathrm{T}-\mathrm{Hg}$ or $\mathrm{MeHg}$ and $\mathrm{OM}$ (particularly DOC) has been demonstrated in a number of river systems, although it has not been observed in all lotic systems, and the underlying principles were not studied (Lavoie et al., 2019, for a global analysis; Zolkos et al., 2020, for major arctic rivers; De Bonville et al., 2020, for the boreal Romaine river watershed). Bravo et al. (2018) studied 29 streams across Europe at latitudes ranging from 41 to $64^{\circ} \mathrm{N}$ and demonstrated that autochthonous DOM and the availability of electron acceptors for $\mathrm{Hg}$ methylating microorganisms (e.g., sulfate) drive the percentage of $\mathrm{MeHg}$, and potentially $\mathrm{MeHg}$ concentrations, in water. As has been observed in lakes and reservoirs, autochthonous carbon seems to stimulate bacterial metabolism and community plasticity in riverine systems (Comte and Del Giorgio, 2011). Through a crossover effect, this local carbon source would increase mercury methylation by enhancing the assimilation of allochthonous DOM (the main carbon source for prokaryotic communities in inland waters), which gradually becomes less reactive along the river continuum (Massicotte et al., 2017; LaBrie et al., 2020). On the other hand, Bravo et al. (2018) also found that allochthonous DOM inputs, i.e., dissolved organic matter probably originating from organic-rich catchment soils, control $\mathrm{T}-\mathrm{Hg}$ concentrations in streams; however the authors do not mention the probable mechanisms underlying this interaction, described below.

Although most studies on mercury in lentic systems have focused on its bioaccumulation, in lotic systems, the question of its speciation arose rapidly due to the link between the mercury phase and downstream transport. When the initial evidence of the connection between mercury concentrations and OM in river system s was found, other studies had already linked mercury distribution to iron or manganese concentrations (Gobeil and Cossa, 1993; Quémerais et al., 1998). Concomitantly, Stordal et al. (1996) investigated the mercury bioavailability in the entire dissolved phase (defined as the entire fraction passing through a $0.45-\mu \mathrm{m}$ filter), since they demonstrated that, in the environments studied, $57 \%$ (on average) of the dissolved fraction of $\mathrm{T}-\mathrm{Hg}$ was associated with macromolecules, forming so-called colloids (the size fraction between a few nanometers and $0.45 \mu \mathrm{m}$, which includes macromolecules and microparticles; Droppo, 2006; Buffle et al., 1992). An important characteristic of colloids is their ability to become involved in aggregation reactions, as well as in hydrophilic (e.g., metal ions) and hydrophobic (e.g., oil and other hydrophobic pollutants) binding interactions (Wetzel, 2001; Santschi, 2018). The size and structure of colloids are heavily influenced by changes in water chemistry such as $\mathrm{pH}$, redox potential, ionic strength, and DOM concentration and type, causing aggregation or dispersal of the components and associated elements (Cuss et al., 2020). In 2002, Pokrovsky and Schott revealed the presence, in boreal Russian rivers, of two pools of colloids composed of organicrich and Fe-rich particles, considered to be the most important potential carriers for other elements, which they divided into four groups with different distribution patterns: 1) dissolved simple anions; 2) elements mainly adsorbed on carbon-based colloids; 3 ) 
elements mainly adsorbed on iron-rich colloids; and 4) elements almost equally distributed between carbon colloids and iron colloids (the last being more common; Lyvén et al., 2003). Following this finding, iron and carbon colloidal carrier phases were shown to transport rare earth and trace elements in boreal and subarctic rivers (Anderson et al., 2006; Dahlqvist et al., 2007; Pokrovski et al., 2010; Krickov et al., 2019; Cuss et al., 2020). Complexation of trace elements by OM in colloidal form would decrease their lability (Aiken et al., 2011; Stockdale et al., 2014; Cuss et al., 2020). Recently, technical advances have allowed the two iron-colloid phases to be distinguished (Herzog et al., 2020): $\mathrm{Fe}-\mathrm{OM}$ complexes and $\mathrm{Fe}$ (oxy)hydroxides (as nanoparticles or associated with chromophoric molecular matter) and especially ferrihydrite, which is a common weathering product of $\mathrm{Fe}$ bearing minerals in boreal regions and an efficient trace metal sorbent in the aquatic environment (Wetzel, 2001; Jokinen et al., 2020). Despite our improved knowledge of the iron and carbon colloidal carrier phases, their specific association with mercury along the freshwater continuum is still unknown. Recently, colloids were shown to promote the photodegradation of organic contaminants (Cheng et al., 2021). It becomes clear that further investigations are required on metallic and organic carriers and their capacity to drive $\mathrm{Hg}$ transport and settling along the aquatic continuum from source to estuary.

To sum up, mercury in boreal rivers, which is mainly found in the dissolved phase, likely come from the microbial loop, that feeds on allochthonous OM in lakes and reservoirs. It would be interesting to test this hypothesis, through existing mechanistic model on the reactivity of allochthonous DOM (Vachon et al., 2017), in studying the link between the strength of allochtony and the concentration in $\mathrm{Hg}$ in different compartments of the river foodwebs. The exported dissolved phase, which is subject to changes in water chemistry, is partitioned between truly dissolved and iron or carbon colloidal carrier phases. It could be hypothesized that the observed decrease in OM lability/ reactivity from the lotic source to the estuary is at least partly due to an increase in the proportion of the colloidal phases, the most reactive part of DOM being simply lost due to biological and photochemical degradation. In this case, the proportion of mercury entering the estuaries through colloidal carriers would be preponderant and should be quantified in river systems using the new techniques available. In fact, as discussed in the next section, most studies on this topic do not deal with the riverine continuum but focus instead on the fate of $\mathrm{OM}$ and mercury in the saltwater plumes of estuaries.

\section{ESTUARIES: TRAP OR EXTENDED LIFE CYCLE?}

Fluvial systems terminate in river mouths, which are transitional environments subject to active biogeochemical transformations. The riverine influence is illustrated by the freshwater plume, which depends on the river discharge and the tidal range. Therefore, understanding this plume is fundamental to comprehending the fluvial contributions to the biogeochemistry of the river mouth (Delannoy et al., 2016).
The opposing forces of freshwater and saltwater define the type of river mouth found: ria, estuary, or delta. In Canada, strong marine dynamics and relatively low sediment loads favor the presence of estuaries rather than deltas and major hydropower utilities are located on rivers forming estuaries in the St. Lawrence River, James Bay, Hudson Bay and the Atlantic and Pacific oceans.

To our knowledge, most studies dealing with metal speciation or carbon fate in river mouth systems have been conducted in estuaries rather than in rias or deltas, probably because it is easier to study estuaries (a single channel) than deltas (multiple channels). As discussed in the previous section, studies on mercury phase speciation in fluvial systems are scarce, while studies dealing with mercury behavior in estuarine ecosystems are more common, partly because of the intriguing question of the fate of the organic matter, particularly the colloid phases, during estuarine mixing. Consequently, the objective of this section is to determine the most probable fate of mercury at the end of the freshwater continuum and influence.

\section{Organic Matter Loadings in the Estuarine Carbon Cycle: The Relative Importance of Flocculation}

In 1988, at a time when the interest in mercury in freshwater was waning after twenty years in the spotlight, Cossa et al., highlighted the importance of estuarine biochemical processes in determining the mass balance budget for dissolved mercury at river-ocean margins. These authors were among the first to observe decreasing dissolved $\mathrm{Hg}$ concentrations across the salinity gradient of the St-Lawrence estuary; they concluded that $50-85 \%$ of the dissolved $\mathrm{Hg}$ was linked to $\mathrm{OM}$ and hypothesized that $\mathrm{Hg}$ removal was due to flocculation of the colloid phase of the OM, which was enhanced by iron. As explained in From Reservoirs or Lakes to Estuaries: Evidence of the Joint Export of Carbon and Mercury, the role of iron as a colloidal carrier has been recently demonstrated. The aggregation/flocculation of $\mathrm{OM}$ in estuaries, triggered by the change in ionic strength and increased cation concentrations, had already been demonstrated in laboratory experiments by Sholkovitz (1976), and had also been used to explain the decrease in trace elements in seawater ( $\mathrm{Li}$ et al., 1984). Flocculation alters the chemical composition of DOC by removing the humic compounds and reducing its molecular size, transforming DOC into particulate organic flocs, which can sediment and/ or be consumed by grazers and filter feeders, and also stimulates the bacterial degradation of the flocculated DOC (Tranvik and Sieburth, 1989).

Subsequently, the conversion of dissolved OM into terrestrialorigin particulate organic matter (POM) through colloid-phase flocculation was demonstrated in subtropical (Benner and Opsahl, 2001), temperate (St. Pierre et al., 2020), boreal (Asmala et al., 2014; Kritzberg et al., 2014; Herzog et al., 2020) and arctic (Gonçalves-Araujo et al., 2015; Soerensen et al., 2017; Kipp et al., 2020) coastal waters. Flocculation is one of the marginal filter (or coastal filter) processes described by Lisitsyn (1995), who estimated that, in the world's rivers, 
$93-95 \%$ of the suspended matter and $20-40 \%$ of the dissolved matter in river discharge (pollution included) is deposited in mixing areas on average. Key parameters influencing the DOM pool and consequently the flocculation process include DOM quality and quantity, flow conditions and residence time (Asmala et al., 2016). For example, Palmer et al. (2015), in a study in the United Kingdom, examined estuarine mixing in rivers with peatland catchments, where carbon concentrations are dominated by DOC. These authors did not find any evidence of the consistent estuarine processing of riverine carbon. Instead, they found "hot moments" during which untransformed peatderived DOC was more susceptible to flocculation and other removal processes. According to their results, DOC flocculation is more likely to happen in autumn, when terrestrial DOC inputs peak and shorter residence times in the freshwater system likely limit the breakdown of the humic acid component of DOC. The authors observed 30\% DOC loss during estuarine freshwater mixing under these conditions. Photodegradation has also been shown to be one of the marginal filters that promote the flocculation of DOC into particulate organic carbon in saltwater environments (Jones et al., 2015). Subsequently, colloidal flocculation was examined and then integrated in global carbon budgets (Bauer et al., 2013) and models (Anderson et al., 2019). However, in freshwaters, the dissolved phase is not necessarily dominated by carbon colloids, and iron colloids are also critical (Pokrovsky and Schott, 2002; Lyvén et al., 2003). Concomitant to these advances in carbocentric science, several important studies on iron fate demonstrated the importance of the flocculation process and of estuarine burial. Unsurprisingly, Herzog et al. (2017) obtained contrasting results to those described above: their experiments, with water sampled from six boreal rivers in Sweden, demonstrated the absence of DOC flocculation with increased salinity (in this case, DOC may be primarily composed of truly dissolved carbon rather than colloid carbon), and instead found a targeted aggregation process dependent on iron speciation. Iron is known to be a key colloidal carrier in rivers and also behaves non-conservatively along the river-ocean continuum, i.e., it undergoes aggregation and sedimentation in estuaries. Several mechanisms could be responsible for the destabilization and flocculation of Fe colloidal carrier phases along salinity gradients (Kritzberg et al., 2014). A higher iron:organic carbon ratio would make Fe more prone to aggregate; and the dissolved Fe loss through aggregation in boreal estuaries can vary between 46 and 99\% (Kritzberg et al., 2014; Herzog et al., 2017). More precisely, increased salinity leads to a selective loss by aggregation of Fe (oxy)hydroxide colloids, which have been shown to dominate $\mathrm{Fe}$ speciation in boreal rivers (Herzog et al., 2017; Herzog et al., 2019). The presence of these $\mathrm{Fe}$ (oxy)hydroxide colloids (ferrihydrite particles) in the freshwater Fe pool is responsible for the observed decoupling of $\mathrm{Fe}$ and $\mathrm{OM}$ flocculation and sedimentation in boreal estuaries; in other words, Fe removal during estuarine mixing is far more efficient than that of DOC (Jilbert et al., 2018).

In short, according to the current knowledge, $\mathrm{OM}$ is essentially exported from boreal lakes and reservoirs in the dissolved phase, which can be divided into a truly dissolved and a colloidal phase. Both organic-rich and Fe-rich colloids, which are the main carriers of many rare earth elements and trace metals, have been shown to aggregate in response to salinity (Figure 1F), leading to a colloid loss that may reach almost $100 \%$. So, given its strong link to OM in freshwaters, what happens to mercury in estuaries?

\section{Hg Fate Related to Organic Matter Speciation in Estuaries: Importance of the Particulate vs. Dissolved Phases in Hg Settling and Burial}

Only a few studies specifically deal with mercury fate in estuaries and the possible sedimentation of mercury through the flocculation of the colloidal carrier phases. These studies can be distinguished from one another by the relative importance of the suspended and dissolved OM concentrations in the area studied. In estuaries in Texas (Stordal et al., 1996), France (Coquery et al., 1997) and California (Choe et al., 2003) disturbed by anthropogenic activities, where suspended particulate material (SPM) is more predominant than dissolved material, mercury (forms detailed below) has been found to have a high affinity for SPM, but occurs to a much lesser extent in the dissolved OM phase. The dissolved phase of $\mathrm{T}-\mathrm{Hg}$ was found to be mainly bound to carbon-colloid phases ( $57 \pm 20 \%$ in Texas rivers; $46-88 \%$ in French rivers; $38-57 \%$ in San Francisco Bay), as shown by the strong relationship between colloidal T-Hg and carbon. In these areas dominated by SPM, no evidence was found of colloidal mercury (T-Hg) flocculation accompanying an increase in salinity, and the authors argue instead that a simple dilution of colloidal $\mathrm{Hg}$ and truly dissolved $\mathrm{Hg}$ occurs in seawater (i.e., conservative estuarine mixing) at the edges of the freshwater plume. In these systems, the role of bacterial and phytoplankton biomass in controlling particulate mercury by its direct sorption on cell surfaces would likely be a determining factor in the bioaccumulation of $\mathrm{Hg}$ in food webs (Jang et al., 2014). However, Choe et al. (2003) found a different speciation for $\mathrm{MeHg}$; although $\mathrm{MeHg}$ represented a small portion of the total Hg flux in San Francisco Bay (12.9\%), its fate was important because of its bioaccumulation potential and its toxicity. The authors suggest that colloidal abundance is more important than SPM abundance in influencing $\mathrm{MeHg}$ cycling and transport in the estuary studied. In addition, colloids would have a similar binding capacity with $\mathrm{T}-\mathrm{Hg}$ and $\mathrm{MeHg}$, whereas suspended solids would have a greater binding capacity with $\mathrm{Hg}$. Consequently, in this region, $\mathrm{MeHg}$ was mainly bound to the dissolved phase $(54 \%$ of the total annual MeHg flux) and was primarily associated with colloidal material ( $63 \%$ of the annual riverine flux of dissolved $\mathrm{MeHg}$ ). The authors also found that significant amounts of colloidal (73\%) and dissolved (108\%) $\mathrm{MeHg}$ were removed during estuarine mixing, and that $\mathrm{MeHg}$ removal may be also coupled with iron removal by flocculation (Flegal et al., 1991). Finally, estuaries receiving large amounts of SPM are more productive and can therefore contain hypoxic or anoxic waters. Soerensen et al. (2018) showed that anoxic seawaters with high concentrations of dissolved sulfide cause the formation of dissolved species of $\mathrm{Hg}^{\mathrm{II}}$ available for methylation, which 


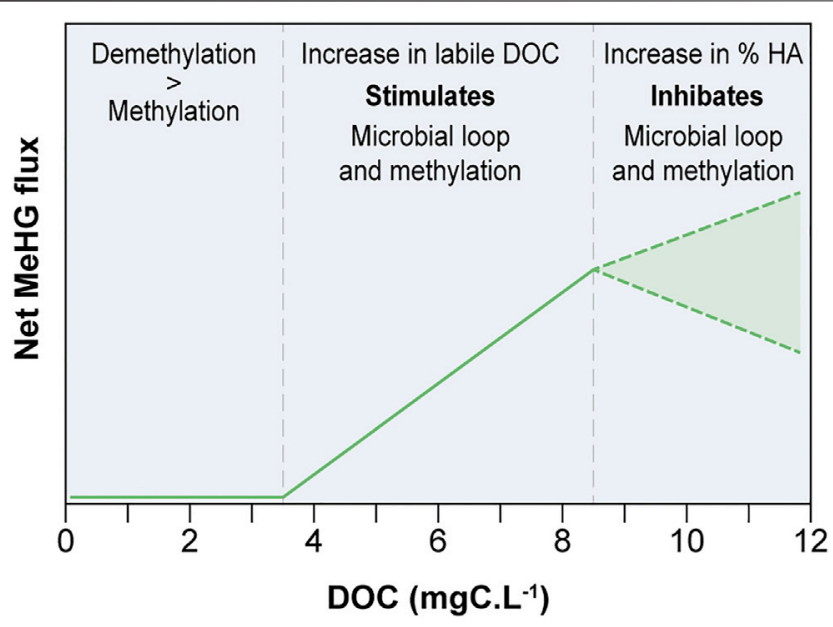

FIGURE 3 | Conceptual representation of the influence of DOC concentration on net aquatic $\mathrm{MeHg}$ flux in freshwater. HA: Humic acids (adapted from French et al. (2014), Soerensen et al. (2017)). Dash lines represent the limit of the probable variation of the net $\mathrm{MeHg}$ flux.

exposes zooplankton to MeHg. To summarize, rivers with a high SPM load appear to export particulate mercury to estuaries, where its lifetime is extended through biological or chemical processes that lead to probable methylation and bioaccumulation in the food webs.

In boreal rivers, the fate of mercury is likely quite different, since the vast majority of the total organic carbon in these systems occurs in the form of DOC (94\%), because of the retention capacity of the organic matter of the numerous lakes and wetlands found in the boreal biome (Mattsson et al., 2005). Consequently, $\mathrm{Hg}$ and $\mathrm{MeHg}$ are probably greatly influenced by the colloidal phases and to a lesser extent by the truly dissolved phase, while SPM would be negligible. To our knowledge, no recent study has tested these hypotheses in boreal areas. The most similar study in terms of the ecosystem studied was conducted by Soerensen et al. (2017) in the northern Baltic Sea. The authors found that, in the subarctic river examined, which has a low SPM content, dissolved total $\mathrm{Hg}$ accounted for $87-99 \%$ of the total $\mathrm{Hg}$ pool. The flocculation and subsequent settling of dissolved OM allowed $16-35 \%$ of the total $\mathrm{Hg}$ to be removed from the estuary, while 2-22\% was lost through SPM settling; lastly, $43-82 \%$ of the total $\mathrm{Hg}$ pool was lost through $\mathrm{Hg}^{0}$ evasion (Amyot et al., 1994; Amyot et al., 1997; Guentzel and Tsukamoto, 2001). Regarding SPM settling, it should be noted that freshwater diatoms may dominate the pelagic algal communities in boreal rivers in Quebec in terms of biovolume (Deblois et al., 2020). These organisms would sediment in estuaries (Sculley et al., 2017; Bukaveckas et al., 2019) due to the change in salinity (Gonçalves et al., 2006), and would thus contribute to local OM turnover, based on the same process as flocculation (Figure 1F).

In the bays studied by Soerensen et al. (2017), MeHg only represented from 4 to $4.5 \%$ of total $\mathrm{Hg}$ in freshwater, and only $2.1 \%$ in offshore saltwater, which corresponds to a roughly $50 \%$ reduction in the $\mathrm{MeHg}$ pool through particle and flocculated DOM settling and other competing processes, such as methylation and demethylation. $\mathrm{MeHg}$ concentrations have been positively linked to concentrations of labile DOC, which can thus be used as a proxy for OM remineralization. Interestingly, the authors found a "baseline" concentration of labile DOC in the studied bays $\left(300 \mu \mathrm{M}\right.$, eq. to $\left.3.6 \mathrm{mgC.} \mathrm{L}^{-1}\right)$, below which $\mathrm{MeHg}$ demethylation outcompetes $\mathrm{MeHg}$ production, resulting in net water column demethylation and a depletion of the $\mathrm{MeHg}$ pool. In parallel, they showed that humic substances most likely decrease $\mathrm{Hg}^{\mathrm{II}}$ availability for methylation, either by forming stable complexes with $\mathrm{Hg}^{\mathrm{II}}$ or by converting $\mathrm{Hg}^{\mathrm{II}}$ to $\mathrm{Hg}^{0}$ (Soerensen et al., 2017; Soerensen et al., 2018). French et al. (2014) also demonstrated the negative effect of humic acids in Arctic lakes and found that DOC concentrations above 11.7 mgC. $\mathrm{L}^{-1}$ restrained $\mathrm{Hg}$ bioavailability; they also support older studies showing that the DOC-Hg (bioavailability or bioaccumulation) relationship is not linear. Together, the studies dealing on DOC-Hg underline the fact that in a given river continumm, the origin (allochthonous vs. autochtonous) and lability of the OM will determine thresholds and range for which methylation and bioaccumulation are possible and optimal or on the contrary restricted by the DOC concentrations (Figure 3). In order to focus on the more critical and sensitive habitats in the future, this hypothesis should be tested on boreal watersheds showing a large range in DOC concentration (as done by French et al., for Arctic lakes) related to watershed management or seasonal changes in runoff. Not only do humic substances have a negative effect on $\mathrm{MeHg}$ production, but the bicarbonate component of sea salts noticeably slows the methylation of $\mathrm{Hg}^{\mathrm{II}}$ under both aerobic and anaerobic conditions (Compeau and Bartha, 1985) and the methylation process mainly occurs in anoxic or hypoxic waters (Soerensen et al., 2018). Consequently, based on current knowledge, a decrease in total $\mathrm{Hg}$ availability in the water column would occur in pristine normoxic boreal estuaries, especially in terms of $\mathrm{MeHg}$ bioavailability to food webs.

But what happens to settled particles containing $\mathrm{T}-\mathrm{Hg}$ and $\mathrm{MeHg}$ ? According to several studies, $\mathrm{MeHg}$ concentrations in bulk estuarine/marine sediments are not related to $\mathrm{MeHg}$ concentrations in the water column (Taylor et al., 2019) and are not the primary determinants of $\mathrm{MeHg}$ entry into the food web (Amirbahman et al., 2013; Buckman et al., 2019). Instead, in some north Atlantic estuaries with low SPM concentrations and a high proportion of dissolved $\mathrm{MeHg}$ relative to particulate $\mathrm{MeHg}$, $\mathrm{MeHg}$ levels in biota were found to be strongly related to dissolved $\mathrm{MeHg}$ concentrations (Taylor et al., 2019). This suggests that, once settled, $\mathrm{Hg}$ particles are not susceptible to rapid recycling and that remaining $\mathrm{MeHg}$ loads from catchment runoff (rather than direct exposure to the sediment itself), is the main source of bioaccumulation in food webs (Jonsson et al., 2014; Buckman et al., 2019). This corroborates the results obtained by Jokinen et al. (2020), which show sediment sequestration in the estuary for terrestrial $\mathrm{OM}$, ferrihydrite, $\mathrm{Cd}, \mathrm{Pb}, \mathrm{Sn}$, and $\mathrm{Zn}$. The authors argue that trace metals in boreal rivers and estuaries are often associated with Fe-rich organo-mineral colloids and that their sedimentation through flocculation constitutes a substantial long-term sink for trace metals, a process widely referred to as colloids' scavenging effect 
(Santschi, 2018). Consequently, we hypothesize that total Hg and $\mathrm{MeHg}$ should have the same fate in boreal estuaries, since most $\mathrm{Hg}^{\mathrm{II}}$ and $\mathrm{MeHg}$ present in the environment is dissolved and complexed by OM (Ravichandran, 2004; Soerensen et al., 2017).

\section{CONCLUSION}

Although more targeted studies are required, this literature review sheds light on the most probable fate of $\mathrm{Hg}$ along the fresh to saltwater continuum in boreal systems. A schematic representation of the different compartments of the river continuum attempts to summarize the main processes that come out the review (Figure 1). The literature demonstrates that, whether or not rivers are affected by reservoir impoundment, $\mathrm{Hg}$ is mainly transported in the dissolved phase combined with iron or carbon colloidal carriers, therefore limiting its bioavailability along the aquatic continuum to the estuary. Increased mercury concentrations in the dissolved phase, SPM and plankton resulting from reservoir creation are limited to the 10 year period after impoundment. Fish do not contribute significantly to $\mathrm{Hg}$ transport along the continuum. Owing to Québec's geography, the estuaries of most rivers are small in comparison to the vast expanses of saltwater found in the St.-Lawrence River, James Bay and Hudson Bay, resulting in a very limited freshwater influence at the river mouths. Consequently, it is unlikely that $\mathrm{Hg}$ exports to estuaries have an influence beyond the limited area of rivers'

\section{REFERENCES}

Ågren, A., BuffamJansson, I. M., Jansson, M., and Laudon, H. (2007). Importance of Seasonality and Small Streams for the Landscape Regulation of Dissolved Organic Carbon export. J. Geophys. Res. 112, G03003. doi:10.1029/2006JG000381

Aiken, G. R., Hsu-Kim, H., and Ryan, J. N. (2011). Influence of Dissolved Organic Matter on the Environmental Fate of Metals, Nanoparticles, and Colloids. Environ. Sci. Technol. 45 (8), 3196-3201. doi:10.1021/es103992s

Amirbahman, A., Massey, D. I., Lotufo, G., Steenhaut, N., Brown, L. E., Biedenbach, J. M., et al. (2013). Assessment of Mercury Bioavailability to Benthic Macroinvertebrates Using Diffusive Gradients in Thin Films (DGT). Environ. Sci. Process. Impacts 15, 2104-2114. doi:10.1039/c3em00355h

Amyot, M., Gill, G. A., and Morel, F. M. M. (1997). Production and Loss of Dissolved Gaseous Mercury in Coastal Seawater. Environ. Sci. Technol. 31 (12), 3606-3611. doi:10.1021/es9703685

Amyot, M., McQueen, D. J., Mierle, G., and Lean, D. R. S. (1994). Sunlight-Induced Formation of Dissolved Gaseous Mercury in Lake Waters. Environ. Sci. Technol. 28 (13), 2366-2371. doi:10.1021/es00062a 022

Anderson, M. R. (2011). Duration and Extent of Elevated Mercury Levels in Downstream Fish Following Reservoir Creation. River Syst. 19 (3), 167-176. doi:10.1127/1868-5749/2011/019-0023

Anderson, T. R., Rowe, E. C., Polimene, L., Tipping, E., EvansBarry, C. D. C., Barry, C. D. G., et al. (2019). Unified Concepts for Understanding and Modelling Turnover of Dissolved Organic Matter From Freshwaters to the Ocean: The UniDOM Model. Biogeochemistry 146, 105-123. doi:10.1007/s10533-019-00621-1

Andersson, K., Dahlqvist, R., Turner, D., Stolpe, B., Larsson, T., Ingri, J., et al. (2006). Colloidal Rare Earth Elements in a Boreal River: Changing Sources and Distributions During the Spring Flood. Geochim. Cosmochim. Acta 70 (13), 3261-3274. doi:10.1016/j.gca.2006.04.021

Asmala, E., BowersAutio, D. G. R., Autio, R., Kaartokallio, H., and Thomas, D. N. (2014). Qualitative Changes of Riverine Dissolved Organic Matter at Low freshwater plumes. In this mixing zone, changes in ionic strength appear to promote flocculation and the scavenging effect, which immobilize $\mathrm{Hg}$ in the sediment, reducing its bioavailability to the entire food web. In these circumstances, our main findings suggest that reservoir-derived $\mathrm{Hg}$ should not lead to significant, long-term increases in coastal foodwebs in boreal regions characterized by cold, oligotrophic systems. In other words, reservoir impoundment would have a limited impact on human health risks from mercury, which are determined not only by bioavailability in fish but also by communities' consumption habits.

Finally, this study highlights the fact that carbocentric and "mercury-centric" knowledge must be combined to exhaustively understand the processes involved in $\mathrm{Hg}$ transport in watersheds and ultimately be able to use easily measurable parameters to model $\mathrm{MeHg}$ bioaccumulation.

\section{AUTHOR CONTRIBUTIONS}

All authors listed have made a substantial, direct, and intellectual contribution to the work and approved it for publication.

\section{ACKNOWLEDGMENTS}

We thank Jean-François Lapierre (Université de Montréal) for critical discussion and reading of the manuscript.

Salinities Due to Flocculation. J. Geophys. Res. Biogeosci. 119 (10), 1919-1933. doi:10.1002/2014jg002722

Asmala, E., Kaartokallio, H., Carstensen, J., and Thomas, D. (2016). Variation in Riverine Inputs Affect Dissolved Organic Matter Characteristics Throughout the Estuarine Gradient. Front. Mar. Sci. 2, 125. doi:10.3389/fmars.2015.00125

Bastien, J. (2005). "Impacts of Ultraviolet Radiation on Aquatic Ecosystems: Greenhouse Gas Emissions and Implications for Hydroelectric Reservoirs," in Greenhouse Gas Emissions: Fluxes and Processes, Hydroelectric Reservoirs and Natural Environments. Editors A. Tremblay, L. Varfalvy, C. Roehm, and M. Garneau (Berlin, Heidelberg/New York: Springer-Verlag), 510-527.

Bates, B., Kundzewicz, Z. W., Wu, S., and Palutikof, J. (2008). Climate Change and Water. Technical Paper of the Intergovernmental Panel on Climate Change. Geneva, Switzerland: IPCC Secretariat.

Bauer, J. E., Cai, W.-J., Raymond, P. A., Bianchi, T. S., Hopkinson, C. S., and Regnier, P. A. G. (2013). The Changing Carbon Cycle of the Coastal Ocean. Nature 504 (7478), 61-70. doi:10.1038/nature12857

Benner, R., and Opsahl, S. (2001). Molecular Indicators of the Sources and Transformations of Dissolved Organic Matter in the Mississippi River Plume. Org. Geochem. 32 (4), 597-611. doi:10.1016/s0146-6380(00)00197-2

Bilodeau, F., Therrien, J., and Schetagne, R. (2017). Intensity and Duration of Effects of Impoundment on Mercury Levels in Fishes of Hydroelectric Reservoirs in Northern Québec (Canada). Inland Waters 7, 493-503. doi:10.1080/20442041.2017.1401702

Blais, A.-M., Lorrain, S., Plourde, Y., and Varfalvy, L. (2005). "Organic Carbon Densities of Soils and Vegetation of Tropical, Temperate and Boreal Forests," in Greenhouse Gas Emissions: Fluxes and Processes, Hydroelectric Reservoirs and Natural Environments. Editors A. Tremblay, L. Varfalvy, C. Roehm, and M. Garneau (Berlin, Heidelberg/New York: Springer-Verlag), 155-185.

Bo, M., Feng, X., Qiu, G., Li, Z., Yao, H., Shang, L., et al. (2016). The Impacts of Organic Matter on the Distribution and Methylation of Mercury in a Hydroelectric Reservoir in Wujiang River, Southwest China. Environ. Toxicol. Chem. 35 (1), 191-199. doi:10.1002/etc.3181 
Bodaly, R. A., Jansen, W. A., Majewski, A. R., Fudge, R. J. P., Strange, N. E., Derksen, A. J., et al. (2007). Postimpoundment Time Course of Increased Mercury Concentrations in Fish in Hydroelectric Reservoirs of Northern Manitoba, Canada. Arch. Environ. Contam. Toxicol. 53, 379-389. doi:10.1007/s00244-006-0113-4

Bogard, M. J., and Del Giorgio, P. A. (2016). The Role of Metabolism in Modulating CO2 Fluxes in Boreal Lakes. Glob. Biogeochem. Cycles 30 (10), 1509-1525. doi:10.1002/2016gb005463

Boszke, L., Głosińska, G., and Siepak, J. (2002). Some Aspects of Speciation of Mercury in Water Environment. Pol. J. Environ. Stud. 11, 285-298.

Braaten, H. F. V., De Wit, H. A., Fjeld, E., Rognerud, S., Lydersen, E., and Larssen, T. (2014). Environmental Factors Influencing Mercury Speciation in Subarctic and Boreal Lakes. Sci. Total Environ. 476-477, 336-345. doi:10.1016/ j.scitotenv.2014.01.030

Bravo, A. G., Bouchet, S., Tolu, J., Björn, E., Mateos-Rivera, A., and Bertilsson, S. (2017). Molecular Composition of Organic Matter Controls Methylmercury Formation in Boreal Lakes. Nat. Commun. 8, 14255. doi:10.1038/ncomms14255

Bravo, A. G., Kothawala, D. N., Attermeyer, K., Tessier, E., Bodmer, P., Ledesma, J. L. J., et al. (2018). The Interplay Between Total Mercury, Methylmercury and Dissolved Organic Matter in Fluvial Systems: A Latitudinal Study across Europe. Water Res. 144, 172-182. doi:10.1016/j.watres.2018.06.064

Brouard, D., Doyon, J.F., and Schetagne, J. (1994). "Amplification of Mercury Concentration in Lake Whitefish (Coregonus clupeaformis) Downstream From the La Grande 2 Reservoir, James Bay, Québec," in Mercury Pollution, Integration and Synthesis. Editors C. J. Watras and J. W. Huckabee (Boca Raton, FL: CRC Press), 369-379.

Buckman, K. L., Seelen, E. A., Mason, R. P., Balcom, P., Taylor, V. F., Ward, J. E., et al. (2019). Sediment Organic Carbon and Temperature Effects on Methylmercury Concentration: a Mesocosm Experiment. Sci. Total Environ. 666, 1316-1326. doi:10.1016/j.scitotenv.2019.02.302

Buffle, J., Perret, D., and Newman, M. (1992). "The Use of Filtration and Ultrafiltration for Size Fractionation of Aquatic Particles, Colloids, and Macromolecules," in Environmental Particles. Editors J. Buffle and H. P. van Leeuwen (Boca Raton, FL: CRC Press), 171-230.

Bukaveckas, P., Kataržyte, M., Schlegel, A., Spuriene, R., Egerton, T., and Vaiciute, D. (2019). Composition and Settling Properties of Suspended Particulate Matter in Estuaries of the Chesapeake Bay and Baltic Sea Regions. J. Soil. Sediment. 19, 5. doi:10.1007/s11368-018-02224-z

Calder, R. S. D., Schartup, A. T., Li, M., Valberg, A. P., Balcom, P. H., and Sunderland, E. M. (2016). Future Impacts of Hydroelectric Power Development on Methylmercury Exposures of Canadian Indigenous Communities. Environ. Sci. Technol. 50 (23), 13115-13122. doi:10.1021/acs.est.6b04447

Cheng, D., Liu, H., E, Y., Liu, F., Lin, H., and Liu, X. (2021). Effects of Natural Colloidal Particles Derived from a Shallow Lake on the Photodegradation of Ofloxacin and Ciprofloxacin. Sci. Total Environ. 773, 145102. doi:10.1016/ j.scitotenv.2021.145102

Choe, K.-Y., Gill, G. A., and Lehman, R. (2003). Distribution of Particulate, Colloidal, and Dissolved Mercury in San Francisco Bay Estuary. 1. Total Mercury. Limnol. Oceanogr. 48 (4), 1535-1546. doi:10.4319/lo.2003.48.4.1535

Clarkson, T. W. (2002). The Three Modern Faces of Mercury. Environ. Health Perspect. 110 (Suppl. 1), 11-23. doi:10.1289/ehp.02110s111

Cole, J. J., Carpenter, S. R., Kitchell, J. F., and Pace, M. L. (2002). Pathways of Organic Carbon Utilization in Small Lakes: Results From a Whole-Lake $13 \mathrm{C}$ Addition and Coupled Model. Limnol. Oceanogr. 47 (6), 1664-1675. doi:10.4319/lo.2002.47.6.1664

Cole, J. J., Carpenter, S. R., Pace, M. L., Van de Bogert, M. C., Kitchell, J. L., and Hodgson, J. R. (2006). Differential Support of Lake Food Webs by Three Types of Terrestrial Organic Carbon. Ecol. Lett. 9, 558-568. doi:10.1111/j.14610248.2006.00898.x

Cole, J., Prairie, Y., Caraco, N. F., McDowell, W., Tranvik, L., Striegl, R., et al. (2007). Plumbing the Global Carbon Cycle: Integrating Inland Waters into the Terrestrial Carbon Budget. Ecosystems 10 (1), 171-184. doi:10.1007/s10021006-9013-8

Compeau, G. C., and Bartha, R. (1985). Sulfate-Reducing Bacteria: Principal Methylators of Mercury in Anoxic Estuarine Sediment. Appl. Environ. Microbiol. 50 (2), 498-502. doi:10.1128/aem.50.2.498-502.1985

Comte, J., and Del Giorgio, P. A. (2011). Composition Influences the Pathway But Not the Outcome of the Metabolic Response of Bacterioplankton to Resource Shifts. PLoS One 6, e25266. doi:10.1371/journal.pone.0025266
Coquer, M., Cossa, D., Azemard, S., Peretyazhko, T., and Charlet, L. (2003). Methylmercury Formation in the Anoxic Waters of the Petit-Saut Reservoir (French Guiana) and its Spreading in the Adjacent Sinnamary River. J. Phys. IV France 107, 327-331. doi:10.1051/jp4:20030308

Coquery, M., Cossa, D., and Sanjuan, J. (1997). Speciation and Sorption of Mercury in Two Macro-Tidal Estuaries. Mar. Chem. 58 (1-2), 213-227. doi:10.1016/ s0304-4203(97)00036-4

Cossa, D., Gobeil, C., and Courau, P. (1988). Dissolved Mercury Behaviour in the Saint Lawrence Estuary. Estuar. Coast. Shelf Sci. 26, 227-230. doi:10.1016/02727714(88)90052-2

Cuss, C. W., Glover, C. N., Javed, M. B., Nagel, A., and Shotyk, W. (2020). Geochemical and Biological Controls on the Ecological Relevance of Total, Dissolved, and Colloidal Forms of Trace Elements in Large Boreal Rivers: Review and Case Studies. Environ. Rev. 28, 138-163. doi:10.1139/er-2019-0014 Dahlqvist, R., Andersson, K., Ingri, J., Larsson, T., Stolpe, B., and Turner, D. (2007). Temporal Variations of Colloidal Carrier Phases and Associated Trace Elements in a Boreal River. Geochim. Cosmochim. Acta 71, 5339-5354. doi:10.1016/j.gca.2007.09.016

De Bonville, J., Amyot, M., Giorgio, P., Tremblay, A., Bilodeau, F., Ponton, D. E., et al. (2020). Mobilization and Transformation of Mercury Across a Dammed Boreal River are Linked to Carbon Processing and Hydrology. Water Resour. Res. 56, 10. doi:10.1029/2020WR027951

Deblois, C., Demarty, M., and Tremblay, A. (2020). Complexe de la Romaine: Suivi Environnemental 2019 en Phase Exploitation, Océanographie Physique et Biologique, Volume 2: Production Planctonique en Milieu Marin [The Romaine Complex: 2019 Operation-Phase Environmental Follow-Up: Biological and Physical Oceanography, Volume 2: Plankton Production in The Marine Environment]. Montreal, QC, Canada: Hydro Québec.

Del Giorgio, P. A., Cole, J. J., Caraco, N. F., and Peters, R. H. (1999). Linking Planktonic Biomass and Metabolism to Net Gas Fluxes in Northern Temperate Lakes. Ecology 80 (4), 1422-1431. doi:10.1890/0012-9658(1999)080[1422: lpbamt]2.0.co;2

Delannoy, J. J., Deline, P., and Lhénaff, R. (2016). Géographie Physique: Aspects et Dynamique du Géosystème Terrestre. Paris, France: Vuibert.

Depew, D., Burgess, N., AndersonBaker, M. R., Bhavsar, S., Bodaly, R. A., Eckley, C., et al. (2013). An Overview of $\mathrm{Hg}$ Concentrations in Freshwater Fish Species: A National Fish Mercury (Hg) Dataset for Canada. Can. J. Fish. Aquat. Sci. 29 (4), 459-484. doi:10.1139/cjfas-2012-0338

Dominique, Y., Maury-Brachet, R., Muresan, B., Vigouroux, R., Richard, S., Cossa, D., et al. (2007). Biofilm and Mercury Availability as Key Factors for Mercury Accumulation in Fish (Curimata Cyprinoides) From a Disturbed Amazonian Freshwater System. Environ. Toxicol. Chem. 26 (1), 45-52. doi:10.1897/05-649r.1

Downing, J. A., Prairie, Y. T., Cole, J. J., Duarte, C. M., Tranvik, L. J., StrieglMcDowell, R. G. W. H., et al. (2006). The Global Abundance and Size Distribution of Lakes, Ponds, and Impoundments. Limnol. Oceanogr. 51, 2388-2397. doi:10.4319/lo.2006.51.5.2388

Droppo, I. G. (2006). "Filtration in Particle Size Analysis," in Encyclopedia of Analytical Chemistry. Editor R. A. Meyers (Chichester, United Kingdom: John Wiley \& Sons Ltd), 5397-5413.

Drott, A., Lambertsson, L., Björn, E., and Skyllberg, U. (2008). Do Potential Methylation Rates Reflect Accumulated Methyl Mercury in Contaminated Sediments?. Environ. Sci. Technol. 42 (1), 153-158. doi:10.1021/es0715851

Emery, K. A., Wilkinson, G. M., Ballard, F. G., and Pace, M. L. (2015). Use of Allochthonous Resources by Zooplankton in Reservoirs. Hydrobiologia 758, 257-269. doi:10.1007/s10750-015-2338-6

Ferreira-Rodríguez, N., Castro, A. J., Tweedy, B. N., Quintas-Soriano, C., and Vaughn, C. C. (2021). Mercury Consumption and Human Health: Linking Pollution and Social Risk Perception in the Southeastern United States. J. Environ. Manage. 282, 111528. doi:10.1016/j.jenvman.2020.111528

Flegal, A., Smith, G., Gill, G., Sañudo-Wilhelmy, S., and Anderson, L. (1991). Dissolved Trace Element Cycles in the San Francisco Bay Estuary. Mar. Chem. 36 (1-4), 329-363. doi:10.1016/s0304-4203(09)90070-6

French, T. D., Houben, A. J., Desforges, J.-P. W., Kimpe, L. E., Kokelj, S. V., Poulain, A. J., et al. (2014). Dissolved Organic Carbon Thresholds Affect Mercury Bioaccumulation in Arctic Lakes. Environ. Sci. Technol. 48 (6), 3162-3168. doi:10.1021/es403849d

Gingras, B., Slattery, S., Smith, K., and Darveau, M. (2016). "Boreal Wetlands of Canada and the United States of America," in The Wetland Book. Editors 
C. M. Finlayson, M. Everard, K. Irvine, R. J. McInnes, B. A. Middleton, A. A. van Dam, and N. C. Davidson (Dordrecht, Netherlands: Springer), 1-23. Gobeil, C., and Cossa, D. (1993). Mercury in Sediments and Sediment Pore Water in the Laurentian Trough. Can. J. Fish. Aquat. Sci. 50 (8), 1794-1800. doi:10.1139/f93-201

Gonçalves, A. M. M., De Figueiredo, D. R., and Pereira, M. J. (2006). The Effects of Different Salinity Concentrations on Growth of Three Freshwater Green Algae. Fresen. Environ. Bull. 15, 1382-1386.

Gonçalves-Araujo, R., Stedmon, C. A., Heim, B., Dubinenkov, I., Kraberg, A., Moiseev, D., et al. (2015). From Fresh to Marine Waters: Characterization and Fate of Dissolved Organic Matter in the Lena River Delta Region, Siberia. Front. Mar. Sci. 2, 108. doi:10.3389/fmars.2015.00108

Goyer, R. A., and Clarkson, T. W. (2001). "Toxic Effects of Metals," in Casarett and Doull's Toxicology: The Basic Science of Poisons. Editor C. D. Klaasen (New York, NY: McGraw-Hill), 811-867.

Grosbois, G., Vachon, D., Del Giorgio, P., and Rautio, M. (2020). Efficiency of Crustacean Zooplankton in Transferring Allochthonous Carbon in a Boreal lake. Ecology 101, 6. doi:10.1002/ecy.3013

Guentzel, J. L., and Tsukamoto, Y. (2001). Processes Influencing Mercury Speciation and Bioconcentration in the North Inlet-Winyah Bay Estuary, South Carolina, USA. Mar. Pollut. Bull. 42, 615-619. doi:10.1016/s0025326x $(01) 00090-\mathrm{x}$

Guillemette, F., Leigh McCallister, S., and Del Giorgio, P. A. (2015). Selective Consumption and Metabolic Allocation of Terrestrial and Algal Carbon Determine Allochthony in Lake Bacteria. ISME J. 10, 1373-1382. doi:10.1038/ismej.2015.215

Hall, B. D., Louis, V. L. S., Rolfhus, K. R., Bodaly, R. A., Beaty, K. G., Paterson, M., et al. (2005). Impacts of Reservoir Creation on the Biogeochemical Cycling of Methyl Mercury and Total Mercury in Boreal upland Forests. Ecosystems 8, 248-266. doi:10.1007/s10021-003-0094-3

Health Canada (2007). Human Health Risk Assessment of Mercury in Fish and Health Benefits of Fish Consumption. Ottawa, ON: Health Canada.

Herzog, S. D., Conrad, S., Ingri, J., Persson, P., and Kritzberg, E. S. (2019). Spring Flood Induced Shifts in Fe Speciation and Fate at Increased Salinity. Appl. Geochem. 109, 104385. doi:10.1016/j.apgeochem.2019.104385

Herzog, S. D., Gentile, L., Olsson, U., Persson, P., and Kritzberg, E. S. (2020). Characterization of Iron and Organic Carbon Colloids in Boreal Rivers and Their Fate at High Salinity. J. Geophys. Res. Biogeosci. 125, 4. doi:10.1029/ 2019JG005517

Herzog, S. D., Persson, P., and Kritzberg, E. S. (2017). Salinity Effects on Iron Speciation in Boreal River Waters. Environ. Sci. Technol. 51 (17), 9747-9755. doi:10.1021/acs.est.7b02309

Hoes, O. A. C., Meijer, L. J. J., van der Ent, R. J., and van de Giesen, N. C. (2017). Systematic High-Resolution Assessment of Global Hydropower Potential. PLoS One 12 (2), e0171844. doi:10.1371/journal.pone.0171844

Houel, S., Louchouarn, P., Lucotte, M., Canuel, R., and Ghaleb, B. (2006). Translocation of Soil Organic Matter Following Reservoir Impoundment in Boreal Systems: Implications for In Situ Productivity. Limnol. Oceanogr. 51 (3), 1497-1513. doi:10.4319/lo.2006.51.3.1497

Huttunen, J. T., Hammar, T., Manninen, P., Servomaa, K., and Martikainen, P. J. (2004). Potential Springtime Greenhouse Gas Emissions From a Small Southern Boreal Lake (Keihäsjärvi, Finland). Boreal Env. Res. 9, 421-427.

ICOLD. (2016). Global climate change, dams, reservoirs and related water resources. Available at: https://www.icold-cigb.org/GB/publications/bulletins.asp (Accessed September 2020).

ICOLD. (2021). World Register of Dams. Available at: https://www.icold-cigb.org/ article/GB/world_register/general_synthesis/classification-by-reservoir-capacity (Accessed May 13, 2021).

Ikingura, J., and Akagi, H. (2003). Total Mercury and Methylmercury Levels in Fish From Hydroelectric Reservoirs in Tanzania. Sci. Total Environ. 304 (1-3), 355-368. doi:10.1016/s0048-9697(02)00581-8

Jang, J., Kim, H., and Han, S. (2014). Influence of Microorganism Content in Suspended Particles on the Particle-Water Partitioning of Mercury in SemiEnclosed Coastal Waters. Sci. Total Environ. 470-471, 1558-1564. doi:10.1016/ j.scitotenv.2013.08.097

Jilbert, T., Asmala, E., Schröder, C., Tiihonen, R., Myllykangas, J.-P., Virtasalo, J. J., et al. (2018). Impacts of Flocculation on the Distribution and Diagenesis of Iron in Boreal Estuarine Sediments. Biogeosciences 15, 1243-1271. doi:10.5194/bg15-1243-2018

Jokinen, S. A., Jilbert, T., Tiihonen-Filppula, R., and Koho, K. (2020). Terrestrial Organic Matter Input Drives Sedimentary Trace Metal Sequestration in a Human-Impacted Boreal Estuary. Sci. Total Environ. 717, 137047. doi:10.1016/ j.scitotenv.2020.137047

Jones, T. G., Evans, C. D., Jones, D. L., Hill, P. W., and Freeman, C. (2015). Transformations in DOC Along a Source to Sea Continuum; Impacts of PhotoDegradation, Biological Processes and Mixing. Aquat. Sci. 78, 433-446. doi:10.1007/s00027-015-0461-0

Jonsson, S., Skyllberg, U., Nilsson, M. B., Lundberg, E., Andersson, A., and Björn, E. (2014). Differentiated Availability of Geochemical Mercury Pools Controls Methylmercury Levels in Estuarine Sediment and Biota. Nat. Commun. 5, 4624. doi:10.1038/ncomms5624

Kalff, J. (2002). Limnology: Inland Water Ecosystems. Upper Saddle River, NJ: Prentice-Hall.

Kasper, D., Forsberg, B. R., Amaral, J. H. F., Leitão, R. P., Py-Daniel, S. S., Bastos, W. R., et al. (2014). Reservoir Stratification Affects Methylmercury Levels in River Water, Plankton, and Fish Downstream From Balbina Hydroelectric Dam, Amazonas, Brazil. Environ. Sci. Technol. 48 (2), 1032-1040. doi:10.1021/ es4042644

Kasper, D., Palermo, E. F. A., Branco, C. W. C., Malm, O., and Malm, O. (2012). Evidence of Elevated Mercury Levels in Carnivorous and Omnivorous Fishes Downstream From an Amazon Reservoir. Hydrobiologia 694, 87-98. doi:10.1007/s10750-012-1133-x

Kipp, L., Henderson, P., Wang, Z., and Charette, M. (2020). Deltaic and Estuarine Controls on Mackenzie River Solute Fluxes to the Arctic Ocean. Estuar. Coasts. 43 (1-2), 1992-2014. doi:10.1007/s12237-020-00739-8

Kortelainen, P., Rantakari, M., Alm, J., Larmola, T., Juutinen, S., Bergström, I., et al. (2013). $\mathrm{N}_{2} \mathrm{O}$ Concentrations in Boreal Lakes are Linked to Nitrate and Temperature. Geophys. Res. Abstr. 15, EGU2013-6948.

Krickov, I., Lim, A., Manasypov, R., Loiko, S., Vorobyev, S., Shevchenko, V., et al. (2019). Major and Trace Elements in Suspended Matter of Western Siberian Rivers: First Assessment Across Permafrost Zones and Landscape Parameters of Watersheds. Geochim. Cosmochim. Acta 269, 429-450. doi:10.1016/ j.gca.2019.11.005

Kritzberg, E. S., Bedmar Villanueva, A., Jung, M., and Reader, H. E. (2014). Importance of Boreal Rivers in Providing Iron to Marine Waters. PLoS One 9 (9), e107500. doi:10.1371/journal.pone.0107500

Kuusela, K. (1992). "The Boreal forest: An Overview," in Unasylva: An International Journal of Forestry and Forest Industri. Editor S. A. Dembner (FAO Publication).

Kwon, S. Y., Selin, N. E., Giang, A., Karplus, V. J., and Zhang, D. (2018). Present and Future Mercury Concentrations in Chinese rice: Insights from Modeling. Glob. Biogeochem. Cycles 32, 437-462. doi:10.1002/2017GB005824

LaBrie, R., Lapierre, J. F., and Maranger, R. (2020). Contrasting Patterns of Labile and Semilabile Dissolved Organic Carbon From Continental Waters to the Open Ocean. J. Geophys. Res. Biogeosci. 125, e2019JG005300. doi:10.1029/ 2019JG005300

Lapierre, J.-F., and del Giorgio, P. A. (2014). Partial Coupling and Differential Regulation of Biologically and Photochemically Labile Dissolved Organic Carbon Across Boreal Aquatic Networks. Biogeosciences 11, 5969-5985. doi:10.5194/bg-11-5969-2014

Lavoie, R. A., Amyot, M., and Lapierre, J. F. (2019). Global Meta-Analysis on the Relationship between Mercury and Dissolved Organic Carbon in Freshwater Environments. J. Geophys. Res. Biogeosci. 124 (6), 1508-1523. doi:10.1029/ 2018jg004896

Lázaro, W. L., Díez, S., Bravo, A. G., da Silva, C. J., Ignácio, Á. R. A., and Guimaraes, J. R. D. (2019). Cyanobacteria as Regulators of Methylmercury Production in Periphyton. Sci. Total Environ. 668, 723-729. doi:10.1016/j.scitotenv.2019.02.233

Lee, Y.-H., and Iverfeldt, Å. (1991). Measurement of Methylmercury and Mercury in Run-Off, Lake and Rain Waters. Water Air Soil Pollut. 56, 309-321. doi:10.1007/bf00342279

Li, Y.-H., Burkhardt, L., and Teraoka, H. (1984). Desorption and Coagulation of Trace Elements during Estuarine Mixing. Geochim. et Cosmochim. Acta 48, 1879-1884. doi:10.1016/0016-7037(84)90371-5

Lisitsyn, A. P. (1995). The Marginal Filter of the Ocean. Oceanology 34, 671-682. 
Louchouarn, P., Lucotte, M., Mucci, A., and Pichet, P. (1993). Geochemistry of Mercury in Two Hydroelectric Reservoirs in Quebec, Canada. Can. J. Fish. Aquat. Sci. 50, 269-281.

Lucotte, M., Montgomery, S., and Bégin, M. (1999). "Mercury Dynamics at the Flooded Soil-Water Interface in Reservoirs of Northern Québec: In Situ Observations," in Mercury in the Biogeochemical Cycle. Editors M. Lucotte, R. Schetagne, N. Thérien, C. Langlois, and A. Tremblay (New York/Berlin/ Heidelberg:Springer-Verlag), 165-189.

Lucotte, M., Paquet, S., and Moingt, M. (2016). Climate and Physiography Predict Mercury Concentrations in Game Fish Species in Quebec Lakes Better Than Anthropogenic Disturbances. Arch. Environ. Contam. Toxicol. 70, 710-723. doi:10.1007/s00244-016-0261-0

Lyvén, B., Hassellöv, M., Turner, D. R., Haraldsson, C., and Andersson, K. (2003). Competition Between Iron- and Carbon-Based Colloidal Carriers for Trace Metals in a Freshwater Assessed Using Flow Field-Flow Fractionation Coupled to ICPMS. Geochim. Cosmochim. Acta 67, 3791-3802. doi:10.1016/s00167037(03)00087-5

Mailman, M., Stepnuk, L., Cicek, N., and Bodaly, R. A. (2006). Strategies to Lower Methyl Mercury Concentrations in Hydroelectric Reservoirs and Lakes: A Review. Sci. Total Environ. 368, 224-235. doi:10.1016/j.scitotenv.2005.09.041

Marty, J., and Planas, D. (2005). Source of Carbon for Zooplankton in Lakes and Reservoirs From Northern Quebec, Canada. SIL Proc. 29 (1), 342-344. doi:10.1080/03680770.2005.11902028

Massicotte, P., Asmala, E., Stedmon, C., and Markager, S. (2017). Global Distribution of Dissolved Organic Matter Along the Aquatic Continuum: Across Rivers, Lakes and Oceans. Sci. Total Environ. 609, 180-191. doi:10.1016/j.scitotenv.2017.07.076

Mattsson, T., Kortelainen, P., and Räike, A. (2005). Export of DOM From Boreal Catchments: Impacts of Land Use Cover and Climate. Biogeochemistry 76, 373-394. doi:10.1007/s10533-005-6897-x

McLaughlin, J. (2004). Carbon Assessment in Boreal Wetlands of Ontario. Sault Ste. Marie, Canada: Ontario Forest Research Institute.

Mierle, G., and Ingram, R. (1991). The Role of Humic Substances in the Mobilization of Mercury From Watersheds. Water Air Soil Pollut. 56, 349-357. doi:10.1007/bf00342282

Morel, F. M. M., Kraepiel, A. M. L., and Amyot, M. (1998). The Chemical Cycle and Bioaccumulation of Mercury. Annu. Rev. Ecol. Syst. 29, 543-566. doi:10.1146/ annurev.ecolsys.29.1.543

Moriarity, R. J., Liberda, E. N., and Tsuji, L. J. S. (2020a). Subsistence Fishing in the Eeyou Istchee (James Bay, Quebec, Canada): A Regional Investigation of Fish Consumption as a Route of Exposure to Methylmercury. Chemosphere 258, 127413. doi:10.1016/j.chemosphere.2020.127413

Moriarity, R. J., Liberda, E. N., and Tsuji, L. J. S. (2020b). Using a Geographic Information System to Assess Local Scale Methylmercury Exposure from Fish in Nine Communities of the Eeyou Istchee Territory (James Bay, Quebec, Canada). Environ. Res. 191, 110147. doi:10.1016/j.envres.2020.110147

Mucci, A., Montgomery, S., Lucotte, M., Plourde, Y., Pichet, P., and Tra, H. (1994). Mercury Remobilization From Flooded Soils in a Hydroelectric Reservoir of Northern Quebec, La Grande-2: Results of a Soil Resuspension Experiment. Can. J. Fish. Aquat. Sci. 52, 2507-2517.

Nagler, M., Praeg, N., Niedrist, G. H., Attermeyer, K., Catalán, N., Pilotto, F., et al. (2020). Abundance and Biogeography of Methanogenic and Methanotrophic Microorganisms Across European Streams. J. Biogeogr. 48, 947-960. doi:10.21203/rs.2.17386/v1

Palmer, S. M., Evans, C. D., Chapman, P. J., Burden, A., Jones, T. G., Allott, T. E. H., et al. (2015). Sporadic Hotspots for Physico-Chemical Retention of Aquatic Organic Carbon: from Peatland Headwater Source to Sea. Aquat. Sci. 78, 491-504. doi:10.1007/s00027-015-0448-x

Planas, D., Paquet, S., and Saint-Pierre, A. (2005). "Production-consumption of $\mathrm{CO}_{2}$ in Reservoirs and Lakes in Relation to Plankton Metabolism," in Greenhouse Gas Emissions: Fluxes and Processes, Hydroelectric Reservoirs and Natural Environments. Editors A. Tremblay, L. Varfalvy, C. Roehm, and M. Garneau (Berlin, Heidelberg/New York: Springer-Verlag), 468-482.

Pokrovsky, O. S., and Schott, J. (2002). Iron Colloids/Organic Matter Associated Transport of Major and Trace Elements in Small Boreal Rivers and Their Estuaries (NW Russia). Chem. Geol. 190 (1-4), 141-179. doi:10.1016/s00092541(02)00115-8
Pokrovsky, O. S., Viers, J., Shirokova, L. S., Shevchenko, V. P., Filipov, A. S., and Dupré, B. (2010). Dissolved, Suspended, and Colloidal Fluxes of Organic Carbon, Major and Trace Elements in the Severnaya Dvina River and its Tributary. Chem. Geol. 273, 136-149. doi:10.1016/j.chemgeo.2010.02.018

Porvari, P. (1998). Development of Fish Mercury Concentrations in Finnish Reservoirs From 1979 to 1994. Sci. Total Environ. 213, 279-290. doi:10.1016/s0048-9697(98)00101-6

Porvari, P. (1995). Mercury Levels of Fish in Tucuruí Hydroelectric Reservoir and in River Mojú in Amazonia, in the State of Pará, Brazil. Sci. Total Environ. 175, 109-117. doi:10.1016/0048-9697(95)04907-x

Prairie, Y. T. (2008). Carbocentric Limnology: Looking Back, Looking Forward. Can. J. Fish. Aquat. Sci. 65, 543-548. doi:10.1139/f08-011

Quémerais, B., Cossa, D., Rondeau, B., Pham, T. T., and Fortin, B. (1998). Mercury Distribution in Relation to Iron and Manganese in the Waters of the St. Lawrence River. Sci. Total Environ. 213, 193-201. doi:10.1016/s0048-9697(98) 00092-8

RAMP (2021). Boreal forest and Biodiversity. Available at: http://www.rampalberta.org/river/boreal/canada/physical+environment.aspx [Accessed May 13, 2021].

Ravichandran, M. (2004). Interactions Between Mercury and Dissolved Organic Matter-A Review. Chemosphere 55 (3), 319-331. doi:10.1016/ j.chemosphere.2003.11.011

Regnell, O., and Watras, C. J. (2019). Microbial Mercury Methylation in Aquatic Environments: A Critical Review of Published Field and Laboratory Studies. Environ. Sci. Technol. 53, 4-19. doi:10.1021/acs.est.8b02709

Rudd, J. W. M. (1995). Sources of Methyl Mercury to Freshwater Ecosystems: A Review. Water. Air. Soil. Pollut. 80, 697-713. doi:10.1007/bf01189722

Santschi, P. H. (2018). Marine Colloids, Agents of the Self-Cleansing Capacity of Aquatic Systems: Historical Perspective and New Discoveries. Mar. Chem. 207, 124-135. doi:10.1016/j.marchem.2018.11.003

Schartup, A. T., Ndu, U., Balcom, P. H., Mason, R. P., and Sunderland, E. M. (2016). Contrasting Effects of marine and Terrestrially Derived Dissolved Organic Matter on Mercury Speciation and Bioavailability in Seawater. Environ. Sci. Technol. 49 (10), 5965-5972. doi:10.1021/es506274x

Schetagne, R., Doyon, J., and Fournier, J. (2000). Export of Mercury Downstream From Reservoirs. Sci. Total Environ. 260, 135-145. doi:10.1016/s0048-9697(00) 00557-x

Schetagne, R., Lalumière, R., and Therrien, J. (2006). Suivi environnemental du complexe La Grande. Évolution de la qualité de l'eau. [Rapport technique d'analyse des données de 1978 à 2000]. Montreal, QC, Canada: Genivar Inc. et direction Barrages et Environnement, Hydro-Québec Production.

Schetagne, R., and Therrien, J. (2013). Environmental Monitoring at the La Grande Complex - Evolution of Mercury Levels in Fish. [Summary Report 1978-2012]. Montreal, QC, Canada: Genivar Inc. and Hydro-Quebec Production.

Schetagne, R., and Verdon, R. (1999). "Post-impoundment Evolution of Fish Mercury Levels at the La Grande Complex, Québec, Canada (From 1978 to 1996)," in Mercury in the Biogeochemical Cycle. Editors M. Lucotte, R. Scetagne, N. Thérien, C. Langlois, and A. Tremblay (Berlin, Heidelberg/New York: Springer-Verlag), 235-258.

Schetagne, R. (1994). Water Quality Modifications After Impoundment of Some Large Northern Reservoirs. Adv. Limnol. 40, 223-229.

Sculley, J. B., Lowe, R. L., Nittrouer, C. A., Drexler, T. M., and Power, M. E. (2017). Eighty Years of Food-Web Response to Interannual Variation in Discharge Recorded in River Diatom Frustules From an Ocean Sediment Core. Proc. Natl. Acad. Sci. U.S.A. 114 (38), 10155-10159. doi:10.1073/pnas.1611884114

Sholkovitz, E. R. (1976). Flocculation of Dissolved Organic and Inorganic Matter during the Mixing of River Water and Seawater. Geochim. Cosmochim. Acta 40, 831-845. doi:10.1016/0016-7037(76)90035-1

Skrobonja, A. (2019). Formation, Uptake and Bioaccumulation of Methylmercury in Coastal Seas - a Baltic Sea Case Study, PhD thesis. Umeå (Sweden): Umeå University.

Skyllberg, U., Qian, J., Frech, W., Xia, K., and Bleam, W. F. (2003). Distribution of Mercury, Methyl Mercury and Organic Sulphur Species in Soil, Soil Solution and Stream of a Boreal Forest Catchment. Biogeochemistry 64 (1), 53-76. doi:10.1023/a:1024904502633

Soerensen, A. L., Schartup, A. T., Skrobonja, A., and Björn, E. (2017). Organic Matter Drives High Interannual Variability in Methylmercury Concentrations 
in a Subarctic Coastal Sea. Environ. Pollut. 229, 531-538. doi:10.1016/ j.envpol.2017.06.008

Soerensen, A. L., Schartup, A. T., Skrobonja, A., Bouchet, S., Amouroux, D., LiemNguyen, V., et al. (2018). Deciphering the Role of Water Column Redoxclines on Methylmercury Cycling Using Speciation Modeling and Observations From the Baltic Sea. Glob. Biogeochem. Cycles 32 (10), 1498-1513. doi:10.1029/ $2018 \mathrm{gb} 005942$

St. Louis, V. L., Rudd, J. W. M., Kelly, C. A., Bodaly, R. A., Paterson, M. J., Beaty, K. G., et al. (2004). The Rise and Fall of Mercury Methylation in an Experimental Reservoir†. Environ. Sci. Technol. 38 (5), 1348-1358. doi:10.1021/es034424f

Stockdale, A., Tipping, E., and Lofts, S. (2014). Dissolved Trace Metal Speciation in Estuarine and Coastal Waters: Comparison of WHAM/Model VII Predictions With Analytical Results. Environ. Toxicol. Chem. 34 (1), 53-63. doi:10.1002/ etc. 2789

Stordal, M. C., Gill, G. A., Wen, L.-S., and Santschi, P. H. (1996). Mercury Phase Speciation in the Surface Waters of Three Texas Estuaries: Importance of Colloidal Forms. Limnol. Oceanogr. 41 (1), 52-61. doi:10.4319/lo.1996.41.1.0052

St. Pierre, K. A., Oliver, A. A., Tank, S. E., Hunt, B. P. V., Giesbrecht, I., Kellogg, C. T. E., et al. (2020). Terrestrial Exports of Dissolved and Particulate Organic Carbon Affect Nearshore Ecosystems of the Pacific Coastal Temperate Rainforest. Limnol. Oceanogr. 65 (11), 2657-2675. doi:10.1002/lno.11538

Tadonléké, R. D., Marty, J., and Planas, D. (2012). Assessing Factors Underlying Variation of $\mathrm{CO} 2$ Emissions in Boreal Lakes vs. Reservoirs. FEMS Microbiol. Ecol. 79, 282-297. doi:10.1111/j.1574-6941.2011.01218.x

Tadonléké, R. D., Planas, D., and Paquet, S. (2005). "Bacterial Activity in the Water Column and its Impact on the $\mathrm{CO}_{2}$ Efflux," in Greenhouse Gas Emissions: Fluxes and Processes, Hydroelectric Reservoirs and Natural Environments. Editors A. Tremblay, L. Varfalvy, C. Roehm, and M. Garneau (Berlin, Heidelberg/New York: Springer-Verlag), 468-482.

Taylor, V. F., Buckman, K. L., Seelen, E. A., Mazrui, N. M., Balcom, P. H., Mason, R. P., et al. (2019). Organic Carbon Content Drives Methylmercury Levels in the Water Column and in Estuarine Food Webs Across Latitudes in the Northeast United States. Environ. Pollut. 246, 639-649. doi:10.1016/ j.envpol.2018.12.064

Teisserenc, R., Lucotte, M., Canuel, R., Moingt, M., and Obrist, D. (2014). Combined Dynamics of Mercury and Terrigenous Organic Matter Following Impoundment of Churchill Falls Hydroelectric Reservoir, Labrador. Biogeochemistry 118, 21-34. doi:10.1007/s10533-013-9902-9

Temnerud, J., Seibert, J., Jansson, M., and Bishop, K. (2007). Spatial Variation in Discharge and Concentrations of Organic Carbon in a Catchment Network of Boreal Streams in Northern Sweden. J. Hydrol. 342, 72-87. doi:10.1016/ j.jhydrol.2007.05.015

Tranvik, L. J., and Sieburth, J. M. (1989). Effects of Flocculated Humic Matter on Free and Attached Pelagic Microorganisms. Limnol. Oceanogr. 34 (4), 688-699. doi:10.4319/lo.1989.34.4.0688

Tremblay, A., Lucotte, M., Meili, M., Cloutier, L., and Pichet, P. (1996). Total Mercury and Methylmercury Contents of Insects From Boreal Lakes: Ecological, Spatial and Temporal Patterns. Qual. Res. J. Can. 31 (4), 851-873. doi:10.2166/wqri.1996.047

Tremblay, A., Therrien, J., Hamlin, B., Wichmann, E., and LeDrew, L. J. (2005). "GHG Emissions from Boreal Reservoirs and Natural Aquatic Ecosystems," in
Greenhouse Gas Emissions: Fluxes and Processes, Hydroelectric Reservoirs and Natural Environments. Editors A. Tremblay, L. Varfalvy, C. Roehm, and M. Garneau (Berlin, Heidelberg/New York: Springer-Verlag), 209-232.

Tremblay, G., Legendre, P., Doyon, J.-F., Verdon, R., and Schetagne, R. (1998). The Use of Polynomial Regression Analysis With Indicator Variables for Interpretation of Mercury in Fish Data. Biogeochemistry 40, 189-201. doi:10.1023/a:1005997430906

Tremblay, A., and Lucotte, M. (1997). Accumulation of Total Mercury and Methyl Mercury in Insect Larvae of Hydroelectric Reservoirs. Can. J. Fish. Aquat. Sci. 54, 832-841. doi:10.1139/f96-339

Turgeon, K., Solomon, C. T., Nozais, C., and Gregory-Eaves, I. (2016). Do novel Ecosystems Follow Predictable Trajectories? Testing the Trophic Surge Hypothesis in Reservoirs Using Fish. Ecosphere 7, 12. doi:10.1002/ ecs2.1617

Vachon, D., Prairie, Y., Guillemette, F., and Del Giorgio, P. (2017). Modeling Allochthonous Dissolved Organic Carbon Mineralization Under Variable Hydrologic Regimes in Boreal Lakes. Ecosystems 20, 1-15. doi:10.1007/ s10021-016-0057-0

Verdon, R., Brouard, D., Demers, C., Lalumiere, R., Laperle, M., and Schetagne, R. (1991). Mercury Evolution (1978-1988) in Fishes of the La Grande Hydroelectric Complex, Quebec, Canada. Water Air Soil Pollut. 56, 405-417. doi:10.1007/bf00342287

Verta, M., Rekolainen, S., and Kinnunen, K. (1986). Causes of Increased Fish Mercury Levels in Finnish Reservoirs. Finland: Publications of the Water Research Institute - National Board of Waters, 44-58.

Watras, C. J., Back, R. C., Halvorsen, S., Hudson, R. J. M., Morrison, K. A., and Wente, S. P. (1998). Bioaccumulation of Mercury in Pelagic Freshwater Food Webs. Sci. Total Environ. 219, 183-208. doi:10.1016/s0048-9697(98)00228-9

Wetzel, R. G. (2001). Limnology. 3rd Edn. San Francisco, New York, London: Academic Press.

Xu, J., Liem-Nguyen, V., Buck, M., Bertilsson, S., Björn, E., and Bravo, A. G. (2021). Mercury Methylating Microbial Community Structure in Boreal Wetlands Explained by Local Physicochemical Conditions. Front. Environ. Sci. 8, 518662. doi:10.3389/fenvs.2020.518662

Zhu, S., Zhang, Z., and Žagar, D. (2018). Mercury Transport and Fate Models in Aquatic Systems: A Review and Synthesis. Sci. Total Environ. 639, 538-549. doi:10.1016/j.scitotenv.2018.04.397

Zolkos, S., Krabbenhoft, D. P., Suslova, A., Tank, S. E., McClelland, J. W., Spencer, R. G. M., et al. (2020). Mercury Export From Arctic Great Rivers. Environ. Sci. Technol. 54, 4140-4148. doi:10.1021/acs.est.9b07145

Conflict of Interest: MD was employed by the company Aqua-Consult. FB and AT were employed by the company Hydro-Québec.

Copyright $\odot 2021$ Demarty, Bilodeau and Tremblay. This is an open-access article distributed under the terms of the Creative Commons Attribution License (CC BY). The use, distribution or reproduction in other forums is permitted, provided the original author(s) and the copyright owner(s) are credited and that the original publication in this journal is cited, in accordance with accepted academic practice. No use, distribution or reproduction is permitted which does not comply with these terms. 